UCRL-ID-1129@4

\title{
Measurement of Plutonium and Americium Volatilities Under Thermal Process Conditions: Final Report
}

\author{
Oscar H. Krikorian \\ Ralph H. Condit \\ Alfred S. Fontes, Jr. \\ Dennis L. Fleming \\ Joseph W. Magana \\ Wiilliam F. Morris \\ Martyn G. Adamson
}

April 28, 1993

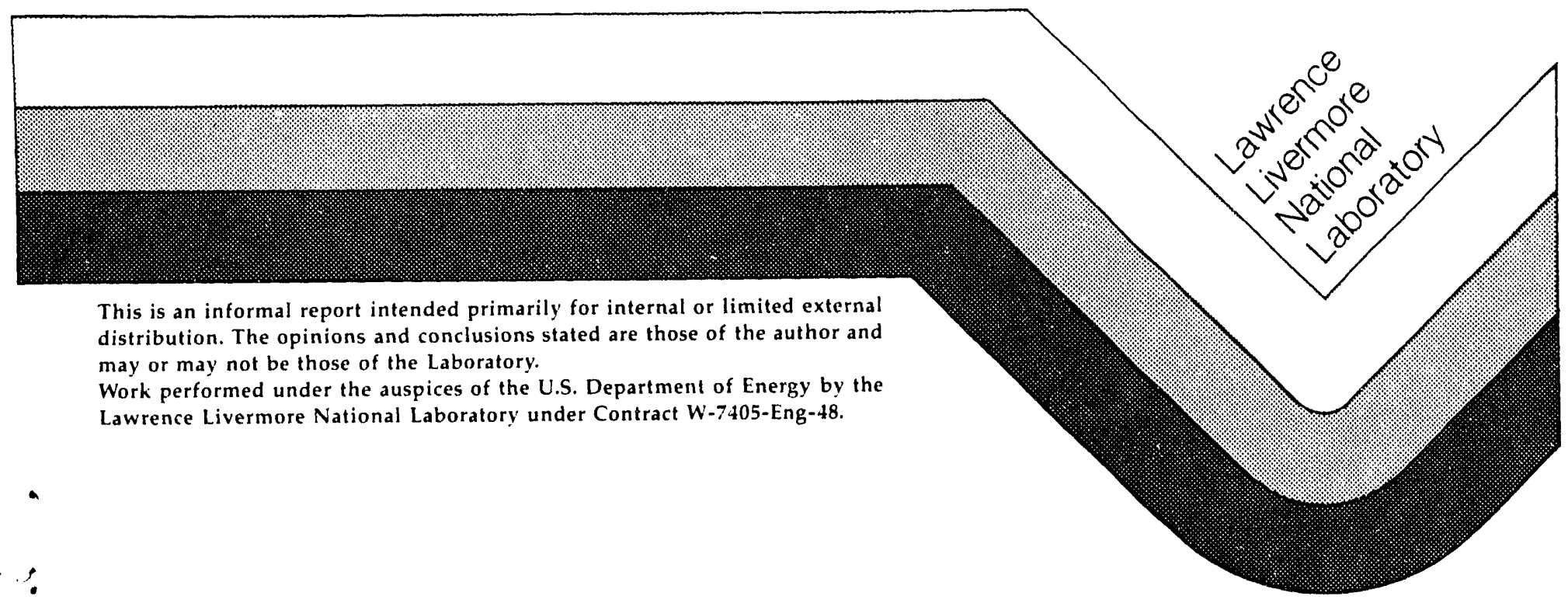




\section{DISCLAIMER}

This document was prepared as an account of work sponsored by an agency of the United States Government. Neither the United States Government nor the University of California nor any of their employees, makes any warranty, express or implied, or assumes any legal liability or responsibility for the accuracy, completeness, or usefulness of any information, apparatus, produch, or process disclosed, or represents that its use would not infringe privately owned rights. Reference herein to any specific commercial products, process, or service by trade name, trademark, manufacturer, or otherwise, does not necessarily constitute or imply its endorsement, recommendation, or favoring by the United States Government or the University of California. The views and opinions of authors expressed herein do not necessarily state or reflect those of the United States Government or the University of California, and shall not be used for advertising or product endorsement purposes.

This report has been reproduced directly from the best available copy.

A vailable to DOE and DOE contractors from the Omice of Scientific and Technical Information P.O. Box 62, Oak Ridge, TN 37831

Prices available from (615) 576-8401, FTS 626-8401

Available to the public from the

National Technical Information Service

U.S. Department of Commerce

5285 Port Royal Rd.,

Springfield, VA 22161 


\title{
Measurement of Plutonium and Americium Volatilities under Thermal Process Conditions: Final Report
}

\author{
Oscar H. Krikorian \\ Ralph H. Condit \\ Alfred S. Fontes, Jr. \\ Dennis L. Fleming \\ Joseph W. Magana \\ William F. Morris \\ Martyn G. Adamson \\ University of California \\ Lawrence Livermore National Laboratory \\ Livermore, CA 94551
}

\section{Abstract}

We have used the transpiration method to measure volatilities of $\mathrm{Pu}$ and $\mathrm{Am}$ from $\mathrm{PuO}_{2}(\mathrm{~s})$ and $\mathrm{PuO}_{2} / 2 \% \mathrm{AmO}_{2}(\mathrm{~s})$ in the presence of stearn and oxygen at temperatures of $1230-1430 \mathrm{~K}$. We find the volatile species to be $\mathrm{PuO}_{2}(\mathrm{OH})_{2}(\mathrm{~g})$ and $\mathrm{AmO}_{2}(\mathrm{OH})_{2}(\mathrm{~g})$ at vapor pressures on the order of $10^{-10} \mathrm{~atm}$ and 10-12 atm respectively under measurement conditions. For the $\mathrm{Pu}$ volatilization reaction, $\mathrm{PuO}_{2}(\mathrm{~s})+1 / 2 \mathrm{O}_{2}(\mathrm{~g})+$ $\mathrm{H}_{2} \mathrm{O}(\mathrm{g})=\mathrm{PuO}_{2}(\mathrm{OH})_{2}(\mathrm{~g})$, we obtain a free energy of reaction of $\Delta \mathrm{GO}_{\mathrm{T}}=231.3-0.0109$ $\mathrm{T}$ in $\mathrm{kJ} / \mathrm{mol}$, and for the Am volatilization reaction, $\mathrm{AmO}_{2}$ (s.s. in $\left.\mathrm{PuO}_{2}\right)+1 / 2 \mathrm{O}_{2}(\mathrm{~g})+$ $\mathrm{H}_{2} \mathrm{O}(\mathrm{g})=\mathrm{AmO}_{2}(\mathrm{OH})_{2}(\mathrm{~g})$, we obtain $\Delta \mathrm{G}^{\circ} \mathrm{T}=223.9-0.0109 \mathrm{~T}$ in $\mathrm{kJ} / \mathrm{mol}$.

We apply these results to the Rocky Flats Plant Fluidized Bed Incinerator to assess the amount of volatile $\mathrm{Pu}$ and $\mathrm{Am}$ produced in the secondary combustor chamber. Taking operating conditions of $550^{\circ} \mathrm{C}$ combustor temperature, $40 \mathrm{kmols} / \mathrm{h}$ of total gas flow at 1 atm pressure, 0.1 atm $\mathrm{O}_{2}(\mathrm{~g}), 0.05$ atm $\mathrm{H}_{2} \mathrm{O}(\mathrm{g}), \mathrm{PuO}_{2}$ (s) containing $200 \mathrm{ppm} \mathrm{AmO} 2$ in the bed, and $6000 \mathrm{~h}$ of operating time per year, gives volatilization rates of $7 \times 10^{-6} \mathrm{~g} \mathrm{Pu} / \mathrm{y}$ and $4 \times 10^{-9} \mathrm{~g} \mathrm{Am} / \mathrm{y}$.

\section{Introduction}

This study has been performed in support of the Rocky Flats Fluidized Bed Incinerator development. The objective of this study has been to conduct experiments to identify the types and amounts of volatile gaseous species of Pu and Am that are produced in the offgases of mixed waste oxidation processors. The primary emphasis has been on the Rocky Flats Fluidized Bed Incinerator, but the results should be of value as well to other mixed waste oxidation processors.

During operation of a mixed waste incinerator or other mixed waste oxidation processor operating under oxidizing conditions, we expect a limited degree of volatilization of actinides to occur and to be carried off by the combustion gases. The vapor phase actinide species that form under these conditions are expected to condense as aerosol particles associated with ash constituents or as condensates on

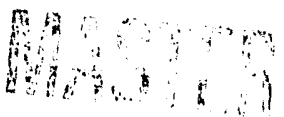


fly ash particulate surfaces, and may not be easily removable from the gas stream by filtration or other means. Therefore, it is important to understand the types and amounts of volatile species produced under various operating conditions so as to maintain proper process controls for containment of the actinides.

Based on available or predicted thermodynamic data [1-5], some small amount of volatility is expected for $\mathrm{U}$ as $\mathrm{UO}_{2}(\mathrm{OH})_{2}(\mathrm{~g})$, for $\mathrm{Pu}$ as $\mathrm{PuO}_{2}(\mathrm{OH})_{2}(\mathrm{~g})$, and for $\mathrm{Am}$ as $\mathrm{AmO}_{2}(\mathrm{OH})_{2}(\mathrm{~g})$ for mixed waste incinerators and other mixed waste oxidation processors operating under oxidizing conditions. Thermodynamic data indicate that other possible gaseous actinide species such as oxides, halides, or oxyhalides, are generally much lower in importance than the oxyhydroxides under incinerator operating conditions; unless halogen acids (e.g., $\mathrm{HCl}$ or $\mathrm{HF}$ ) are present at concentrations greater than $\sim 0.1 \%$ in the gas stream, in which case actinide oxyhalides may also show significant volatilities. [2] The halogen acid content of the Rocky Flats Fluidized Bed incinerator is predicted to be very low because of the presence of sodium carbonate in the bed, which acts as a getter for the halogen acids and converts them to solid sodium halides.

The Rocky Flats Plant Fluidized Bed Incinerator for mixed wastes containing U, $\mathrm{Pu}$, and $\mathrm{Am}$, uses a primary fluidized bed combustor with a mixed $\mathrm{Na}_{2} \mathrm{CO}_{3}$ and $\mathrm{Cr}_{2} \mathrm{O}_{3} / \mathrm{Al}_{2} \mathrm{O}_{3}$ (oxidation catalyst) bed material operated at $550^{\circ} \mathrm{C}$ under pyrolysing conditions and a secondary fluidized bed combustor with a $\mathrm{Cr}_{2} \mathrm{O}_{3} / \mathrm{Al}_{2} \mathrm{O}_{3}$ bed material operated at $550^{\circ} \mathrm{C}$ under oxidizing conditions. $\mathrm{NaCl}$ and $\mathrm{Na}_{2} \mathrm{SO}_{4}$ are produced in the primary bed by interactions of acid gases with $\mathrm{Na}_{2} \mathrm{CO}_{3}$ in the bed. Fly ash produced in the primary combustor is separated out in cyclone separators and the resultant gas stream together with fly ash fines is passed through the secondary bed. Fly ash produced in the secondary combustor consists of mixture of a mineral ash along with $\mathrm{Cr}_{2} \mathrm{O}_{3} / \mathrm{Al}_{2} \mathrm{O}_{3}$ catalyst and small amounts of $\mathrm{Na}_{2} \mathrm{CO}_{3}, \mathrm{NaCl}$ and $\mathrm{Na}_{2} \mathrm{SO}_{4}$ carried through from the primary combustor.

In initial work on this project (funded under sub-contract No. 98661GD from EG\&G Rocky Flats Plant to LLNL), [3] thermodynamic modeling was used to estimate the volatilities of $U$ and $P u$ from both the primary and secondary fluidized bed reaction chambers in the Rocky Flats Plant Fluidized Bed Incinerator. The FACT/EQUILIBRIUM code with its extensive data base was used to carry out these calculations. Additional thermodynamic data on expected $\mathrm{UO}_{2}(\mathrm{OH})_{2}(\mathrm{~g})$ and $\mathrm{PuO}_{2}(\mathrm{OH})_{2}(\mathrm{~g})$ vapor species were input into the data base. The data on $\mathrm{PuO}_{2}(\mathrm{OH})_{2}(\mathrm{~g})$ was estimated using empirical correlations and molecular constant data. Local thermodynamic equilibrium was assumed between the vapor species and the solid materials in the bed. Uranium was found to be present as $\mathrm{Na}_{2} \mathrm{UO}_{4}(\mathrm{~s})$ and $\mathrm{Pu}$ present as $\mathrm{PuO}_{2}(\mathrm{~s})$ in the bed. The volatilization reactions were then given by:

$$
\begin{aligned}
& \mathrm{Na}_{2} \mathrm{UO}_{4}(\mathrm{~s})+\mathrm{H}_{2} \mathrm{O}(\mathrm{g})+\mathrm{CO}_{2}(\mathrm{~g})=\mathrm{Na}_{2} \mathrm{CO}_{3}(\mathrm{~s})+\mathrm{UO}_{2}(\mathrm{OH})_{2}(\mathrm{~g}) \\
& \mathrm{PuO}_{2}(\mathrm{~s})+1 / 2 \mathrm{O}_{2}(\mathrm{~g})+\mathrm{H}_{2} \mathrm{O}(\mathrm{g})=\mathrm{PuO}_{2}(\mathrm{OH})_{2}(\mathrm{~g})
\end{aligned}
$$


Under the pyrolysis conditions of the primary reaction chamber the volatilities of $\mathrm{UO}_{2}(\mathrm{OH})_{2}(\mathrm{~g})$ and $\mathrm{PuO}_{2}(\mathrm{OH})_{2}(\mathrm{~g})$ were found to be quite low $\left(\sim 10^{-19} \mathrm{~atm}\right)$. However, thermodynamic data on other possible volatile $U$ and $P u$ species that may exist under pyrolysis conditions are limited so that a complete assessment of volatility was not made. Further work would be desirable to check for other possible volatile species. In the secondary chamber, under oxidizing conditions, the dominant vapor species were found to be $\mathrm{UO}_{2}(\mathrm{OH})_{2}(\mathrm{~g})$ at $1 \times 10^{-13} \mathrm{~atm}$ and $\mathrm{PuO}_{2}(\mathrm{OH})_{2}(\mathrm{~g})$ at $2 \times 10^{-11} \mathrm{~atm}$. The volatility of $\mathrm{UO}_{2}(\mathrm{OH})_{2}(\mathrm{~g})$ here is substantially lower than if $\mathrm{U}_{3} \mathrm{O}_{8}(\mathrm{~s})$ had been formed. Thus the formation of the mixed oxide $\mathrm{Na}_{2} \mathrm{UO}_{4}(\mathrm{~s})$ significantly reduces the $\mathrm{UO}_{2}(\mathrm{OH})_{2}(\mathrm{~g})$ volatility because of a reduction in uranium oxide activity.

We have also carried out a thermodynamic analysis of $U$ and $\mathrm{Pu}$ volatilities in the Rockwell International Molten Salt Processor, $[2,6-8]$ in which we used an independent assessment of the thermodynamic data for $\mathrm{PuO}_{2}(\mathrm{OH})_{2}(\mathrm{~g})$. The Rockwell International Molten Salt Processor was used to carry out combustion of $U$ - and Pucontaining synthetic laboratory wastes in a molten $\mathrm{Na}_{2} \mathrm{CO}_{3} / \mathrm{NaCl}$ bath at $\sim 1100 \mathrm{~K}$. We took as the volatilization reactions:

$$
\begin{aligned}
& 1 / 3 \mathrm{U}_{3} \mathrm{O}_{8}(\mathrm{~s})+1 / 6 \mathrm{O}_{2}(\mathrm{~g})+\mathrm{H}_{2} \mathrm{O}(\mathrm{g})=\mathrm{UO}_{2}(\mathrm{OH})_{2}(\mathrm{~g}), \\
& \mathrm{PuO}_{2}(\mathrm{~s})+1 / 2 \mathrm{O}_{2}(\mathrm{~g})+\mathrm{H}_{2} \mathrm{O}(\mathrm{g})=\mathrm{PuO}_{2}(\mathrm{OH})_{2}(\mathrm{~g}),
\end{aligned}
$$

We compared the calculated volatilities of $\mathrm{UO}_{2}(\mathrm{OH})_{2}(\mathrm{~g})$ and $\mathrm{PuO}_{2}(\mathrm{OH})_{2}(\mathrm{~g})$ with the amounts of carryover of $U$ and Pu observed in the offgas passages and filters of the Rockwell processor and found agreement to within one to two orders of magnitude. The agreement is as good as can be expected considering the uncertainties in both the calculations and the experimental data.

Applying the two sets of estimated thermodynamic data for volatility of $\mathrm{PuO}_{2}(\mathrm{OH})_{2}(\mathrm{~g})$ to the secondary chamber of the Rocky Flats Plant Incinerator and assuming $\mathrm{Pu}$ to be present as $\mathrm{PuO}_{2}$ (s) gives volatilities of $2 \times 10^{-11}$ atm [3] and $7 \times$ $10^{-13}$ atm [2] for $\mathrm{PuO}_{2}(\mathrm{OH})_{2}(\mathrm{~g})$. Thus, the thermodynamic modeling indicates that $\mathrm{PuO}_{2}(\mathrm{OH})_{2}(\mathrm{~g})$ is an important species, but the predicted volatilities are not very accurate. Experimental measurements would be needed for quantitative data. Also, although $\mathrm{PuO}_{2}$ (s) is assumed to be present as the combustion product, Pu may interact with the ash formed during combustion or with the fluidized bed materials to form mixed oxides or be incorporated in glass phases. These interactions would lead to a lowering of the $\mathrm{PuO}_{2}(\mathrm{~s})$ activity and a consequent lowering of $\mathrm{PuO}_{2}(\mathrm{OH})_{2}(\mathrm{~g})$ volatility. The kinetics of the combustion process and its effect on the resultant volatility of $\mathrm{PuO}_{2}(\mathrm{OH})_{2}(\mathrm{~g})$ also needs to be considered. We expect that both the $\mathrm{PuO}_{2} / \mathrm{ash}$ interactions and combustion kinetic effects would lower $\mathrm{PuO}_{2}(\mathrm{OH})_{2}(\mathrm{~g})$ volatilities as compared to equilibrium volatilization from $\mathrm{PuO}_{2}(\mathrm{~s})$. Our experimental study here of equilibrium volatilities of $\mathrm{PuO}_{2}(\mathrm{OH})_{2}(\mathrm{~g})$ from $\mathrm{PuO}_{2}(\mathrm{~s})$ should therefore provide us with an upper limit estimate of Pu volatilities in the secondany combustor of the Rocky Flats Plant Incinerator. Similar considerations apply to our study here of $\mathrm{AmO}_{2}(\mathrm{OH})_{2}(\mathrm{~g})$ 
volatilities from a $\mathrm{PuO}_{2} / 2 \% \mathrm{AmO}_{2}$ solid solution. The effects of actinide/ash interactions on actinide oxyhydroxide volatilities are currently under study in continuing work on this project.

\section{Approach}

The approach used here to obtain Pu volatilities is to apply the transpiration technique to experimentally measure $\mathrm{Pu}$ volatility from $\mathrm{PuO}_{2}(\mathrm{~s})$ in the presence of $\mathrm{O}_{2}(\mathrm{~g})$ and $\mathrm{H}_{2} \mathrm{O}(\mathrm{g})$, and similarly, to measure $\mathrm{Pu}$ and $\mathrm{Am}$ volatilities from a $\mathrm{PuO}_{2} / 2 \%$ $\mathrm{AmO}_{2}(\mathrm{~s})$ mixed oxide in the presence of $\mathrm{O}_{2}(\mathrm{~g})$ and $\mathrm{H}_{2} \mathrm{O}(\mathrm{g})$. By making measurements on pure $\mathrm{PuO}_{2}(\mathrm{~s})$, we are looking at an upper limit on the volatility, since, as mentioned above, the interactions with ash and the kinetics of vaporization would be expected to lower the volatilities. Use of pure $\mathrm{PuO}_{2}$ (s) also gives us a well-defined state so that we can obtain thermodynamic data on the volatilized species. In working with Am, we are limited in the amount that we can handle in our glovebox system. We chose the $2 \%$ concentration of $\mathrm{AmO}_{2}$ in $\mathrm{PuO}_{2}$ to give adequate detectability of volatilized $\mathrm{Am}$. We analyze the results in terms of whether the Am volatility is enhanced or diminished relative to $\mathrm{Pu}$ volatility. Measurements are run at temperatures high enough for detectability of volatilized $\mathrm{Pu}$ and $\mathrm{Am}$, i.e. temperatures of $900-1200^{\circ} \mathrm{C}$. Results are then extrapolated down to $550^{\circ} \mathrm{C}$, the operating temperature of the Rocky Flats Plant Incinerator. Measurements are also made at $550^{\circ} \mathrm{C}$, to obtain a measured upper limit value for volatility at that temperature.

As a check on the equipment and techniques used to make the transpiration measurements, prior to installing the equipment in the Pu Facility giovebox, we ran some preliminary volatility tests on $\mathrm{WO}_{2}(\mathrm{OH})_{2}(\mathrm{~g})$ for which the volatility data are well established. $[9,10]$

\section{Experimental}

\section{Transpiration Method:}

In the transpiration method, [11] a known amount of carrier gas is slowly passed over a solid or liquid in a furnace chamber, such that any volatile gases produced become entrained in the carrier gas and are swept out of the chamber where the volatilized gas is then condensed and analyzed. The carrier gas may also contain reactive gases that contribute to forming the volatilizing species, such as, for the reaction,

$$
\mathrm{PuO}_{2}(\mathrm{~s})+1 / 2 \mathrm{O}_{2}(\mathrm{~g})+\mathrm{H}_{2} \mathrm{O}(\mathrm{g})=\mathrm{PuO}_{2}(\mathrm{OH})_{2}(\mathrm{~g}) \text {, }
$$

$\mathrm{O}_{2}(\mathrm{~g})$ and $\mathrm{H}_{2} \mathrm{O}(\mathrm{g})$ are both reactive gases that contribute to production of $\mathrm{PuO}_{2}(\mathrm{OH})_{2}(\mathrm{~g})$. Variation of flow rate of the carrier gas permits us to establish the conditions under which the carrier gas becomes saturated with the equilibrium vapor pressure of the volatilizing species. At too slow a flow rate, diffusional transport of the volatilized gas out of the furnace chamber results in values apparently higher than the equilibrium vapor pressure. At too high a flow rate the residence time of the carrier gas in the furnace chamber is not long enough for saturation with the equilibrium 
vapor pressure to occur. At intermediate flow rates, a "plateau" region is estáblished where the equilibrium vapor pressure persists over a range of flow rates. The vapor pressure of the volatilized gas under equilibrium conditions is determined from the ideal gas law by taking the ratio of moles of volatilized species to total moles of gas passed through the chamber to be proportional to the partial pressure of volatilized species to total pressure of the carrier gas passed. The transpiration method also permits us to obtain information on the formula of the volatilizing species. This is done by varying the partial pressures of the reactive gases and noting the law of mass action effects on the volatilizing species. Thus, for the reaction above, we expect the equilibrium partial pressure of $\mathrm{PuO}_{2}(\mathrm{OH})_{2}(\mathrm{~g})$ to be proportional to the $1 / 2$ power of the $\mathrm{O}_{2}(\mathrm{~g})$ pressure and to the first power of the $\mathrm{H}_{2} \mathrm{O}(\mathrm{g})$ pressure. If the volatilizing species were different than $\mathrm{PuO}_{2}(\mathrm{OH})_{2}(\mathrm{~g})$, then the power dependence on $\mathrm{O}_{2}(\mathrm{~g})$ and $\mathrm{H}_{2} \mathrm{O}(\mathrm{g})$ would be accordingly different depending upon the equation stoichiometry.

\section{Description of Apparatus:}

The transpiration equipment in use in the Pu Facility is illustrated schematically in Fig. 1. The equipment is located inside of an air-flow glovebox. The furnace is a Kanthal-heater horizontal clamshell furnace rated to $1200^{\circ} \mathrm{C}$ in air. It provides a uniform-temperature hot zone $\sim 7 \mathrm{~cm}$ long and an overall heated zone $\sim 20 \mathrm{~cm}$ long. The furnace tube is of silica glass, $26 \mathrm{~mm}$ OD $\times 385 \mathrm{~mm}$ long with $35 / 25$ silica glass ball and socket end joints sealed with silicone grease. The boat used to hold the sample is either of $\mathrm{Al}_{2} \mathrm{O}_{3}$ or silica glass. Silica glass (or $\mathrm{Al}_{2} \mathrm{O}_{3}$ ) wool plugs are used in several locations within the furnace tube: one upstream of the boat to define the hot zone, one just downstream of the boat to provide a dust filter, and either one or two further downstream in the lower temperature zone of the furnace to collect the condensate of the volatilized species. These plugs are surrounded by a Pt wire framework to provide for ease in insertion or removal from the furnace tube, and are sized to fit snugly in the tube. Temperatures are measured with type-K thermocouples with inconel sheaths. One thermocouple is located on the outside of the furnace tube at its center, and either one, two, or three thermocouples are located in a silica glass thermocouple probe tube just above the sample boat. These various thermocouples are periodically checked and calibrated against a type-S reference thermocouple. A water saturator is located upstream of the furnace. The water saturator is made of a 6$\mathrm{mm}$-thick wall Al vessel with an $800 \mathrm{~cm}^{3}$ capacity and provided with a fritted stainless steel disperser for the carrier gas, which disperser is located $1 \mathrm{~cm}$ above the bottom of the vessel. Water level is maintained at $500-600 \mathrm{~cm}^{3}$ during the runs. The vessel is heated with a Glas-col mantle. A desiccant cartridge loaded with Drierite $\left(\mathrm{CaSO}_{4}\right)$ is located downstream of the furnace. The cartridge is provided with disconnect fittings to allow weighings to determine water pickup. Gas lines from the water saturator to the furnace and from the furnace to the Drierite cartridge are of stainless steel. Valves are also of stainless steel with Viton rubber seals. A stainless steel to silica glass ball joint connection is used to connect with the furnace tube. Heating tapes are wrapped on the lines from the water saturator to the furnace tube, and from the furnace tube to the Drierite cartridge and maintained at $\sim 150^{\circ} \mathrm{C}$ during the runs to prevent water condensation. Precision Flow Devices PFD-401 mass flow controllers are used to control $\mathrm{O}_{2}$ and Ar flow inputs and to monitor the output gas. Calibrations for these flow meters are provided by the supplier. The flow meters are intercompared periodically 
to check for any changes in calibrations. Weighings are carried out on an Ohaus GT 2100 electronic balance, with a capacity of $2100 \mathrm{~g}$ and an accuracy of $\pm 0.01 \mathrm{~g}$. Certified weights are used periodically to calibrate the balance.

\section{Sample Materials:}

The sample of $\mathrm{PuO}_{2}(\mathrm{~s})$ used in the runs had been formed from electrorefined plutonium. It was in the form of a very fine powder. Calculation of isotopic Pu and Am contents for April 1, 1992, after correcting for radionuclear changes based on a mass spectrometric analysis of the metal on May 10,1990 gave an analysis of $238 \mathrm{Pu} 0.014$ $\%$, $239 \mathrm{Pu} 93.844 \%$, 240Pu $5.872 \%, 241 \mathrm{Pu} 0.221 \%$, 242Pu $0.049 \%$, and $241 \mathrm{Am}$ $0.0264 \%$, all on the basis of metal content. An X-ray diffraction pattern of the $\mathrm{PuO}_{2}$ starting material taken on a powder camera showed single phase $\mathrm{PuO}_{2}$ but with broadened lines consistent with a very fine particulate material. An X-ray diffraction pattern taken after the transpiration heatings again showed single phase $\mathrm{PuO}_{2}$, but with very sharp spotty lines indicating large crystals. The $\mathrm{PuO}_{2} / 2 \% \mathrm{AmO}_{2}$ sample was a reactor grade material. Using an analysis made on this material on March 5, 1986, and converting for radionuclear changes to June 3,1992, just prior to the experiments, we obtain $238 \mathrm{Pu} 0.065 \%$, 239 Pu $80.659 \%$, 240Pu $17.827 \%, 241 \mathrm{Pu}$ $0.989 \%, 242 \mathrm{Pu} 0.460 \%$, and $241 \mathrm{Am} 2.056 \%$, all on the basis of metal content. A sample of $238 \mathrm{PuO}_{2}$ reactor grade material was also used for one run. Isotopic analysis on this material was $238 \mathrm{Pu} 80.33 \%$, 239 Pu $16.55 \%, 240 \mathrm{Pu} 2.54 \%$, $241 \mathrm{Pu}$ $0.398 \%$, and $242 \mathrm{Pu} 0.183 \%$, all on the basis of metal content. The $\mathrm{WO}_{3}$ (s) was obtained from Cerac, Inc, as a -325 mesh powder, with a stated purity of $99.9 \%$. It was yellow green in color as received, but upon heating to $1050^{\circ} \mathrm{C}$ in $\operatorname{Ar}(\mathrm{g}) / \mathrm{H}_{2} \mathrm{O}(\mathrm{g})$ mixtures for the transpiration runs changed to a dark olive green color. X-ray fluorescence analysis taken after the heatings showed $\mathrm{Mo}, \mathrm{Zr}$, and $\mathrm{Y}$ to be present as trace impurities. X-ray diffraction patterns taken after the heatings showed the $\mathrm{WO}_{3}$ to be a mixture of the triclinic [12] and monoclinic [13] forms. The stable form of $\mathrm{WO}_{3}$ at the temperatures of the transpiration experiments is reported to be a tetragonal structure [14] which is stable only above $720^{\circ} \mathrm{C}$. Water used for these experiments had been deionized and then distilled.

\section{Iranspiration Measurements of $\mathrm{WO}_{2}(\mathrm{OH})_{2}(\mathrm{~g})$ Volatility:}

In order to test out the transpiration apparatus on a cold system prior to installing it in a glovebox in the Pu Facility, we carried out transpiration measurements on $\mathrm{WO}_{2}(\mathrm{OH})_{2}(\mathrm{~g})$ volatility according to the reaction,

$$
\mathrm{WO}_{3}(\mathrm{~s})+\mathrm{H}_{2} \mathrm{O}(\mathrm{g})=\mathrm{WO}_{2}(\mathrm{OH})_{2}(\mathrm{~g}) \text {. }
$$

The thermodynamic data for this reaction are well established [9], and accurate transpiration measurement data are also available for this reaction [10] within our temperatures of interest for the Pu and Am volatility studies. 
The experimental procedure used was as follows. We loaded a $2.2 \mathrm{~g}$ sample of $\mathrm{WO}_{3}(\mathrm{~s})$ into an $\mathrm{Al}_{2} \mathrm{O}_{3}$ boat, $1.3 \mathrm{~cm}$ wide $\times 7 \mathrm{~cm}$ long $\times 1 \mathrm{~cm}$ high, and heated sample and boat in air at $1000^{\circ} \mathrm{C}$ for 4 hours prior to use in the transpiration experiments. The boat and sample were then weighed and placed in the furnace (see schematic of apparatus, Fig. 1). In one of the runs $\mathrm{Al}_{2} \mathrm{O}_{3}$ wool plugs were placed in front and behind the boat. In the balance of the runs, plugs were not used. The Drierite cartrioge was weighed and placed in the flow system in a valved-off position. The water bath was heated up to constant temperature (e.g., $75^{\circ} \mathrm{C}$ ) and left open to the air through a stainless steel condenser chamber filled full of stainless steel turnings. The furnace was brought up to reaction temperature under Ar flow with the flow rate controlled at the desired flow' rate with a flow controller. The Ar exiting the furnace was bypassed around the Drierite cartridge and passed through a flow meter and then exhausted to the air. As the furnace temperature was coming up, the heating tapes were also brought up to temperature. When furnace temperature was reached, the $\mathrm{Ar}$ flow was switched to pass through the water bath, with the bath now shut off from the air, and the $\mathrm{Ar} / \mathrm{H}_{2} \mathrm{O}$ flow was passed through the furnace, then through the Drierite cartridge and through the exit flow meter and into the air. Upon completion of the run, the Ar flow was diverted to bypass the water bath, the furnace was turned off, and the Ar allowed to flow through the furnace and the Drierite while the furnace cooled. When cool, the boat and sample were removed and weighed to determine sample weight loss, and the Drierite cartridge was weighed to determine the amount of wate passed through during the run. The amounts of water found were consistent to within $\pm 10 \%$ of the expected values based upon the water bath temperatures and carrier gas flow rates.

The run conditions and results of these transpiration runs are summarized in Table 1. The vapor pressures of $\mathrm{WO}_{2}(\mathrm{OH})_{2}(\mathrm{~g})$ are calculated on the basis of weight loss of $\mathrm{WO}_{3}(\mathrm{~s})$. These vapor pressures are compared in Table 1 with values obtained from JANAF [?]. Agreement is good at Ar flow rates of 25 or $50 \mathrm{~cm} 3 / \mathrm{min}$, but observed vapor pressures are only about half of the literature values at Ar flow rates of 100 $\mathrm{cm}^{3} / \mathrm{min}$. One run made at $200 \mathrm{~cm}^{3} / \mathrm{min}$ in a different furnace with a larger diameter furnace tube, showed about two thirds of the literature value, which is consistent considering that there would be a longer residence time for the gas in the hot zone with the larger diameter. The one run made at an Ar flow rate of $50 \mathrm{~cm} / \mathrm{min}$ using $\mathrm{Al}_{2} \mathrm{O}_{3}$ plugs to reduce diffusional losses out of the hot zone showed no difference from a run under similar conditions without plugs, thus indicating no significant diffusional end losses. Carrier gas flow rates used by Glemser and Haeseler [10] in their transpiration studies of $\mathrm{WO}_{2}(\mathrm{OH})_{2}$ volatility were $50 \mathrm{~cm} / / \mathrm{min}$ over the temperature range of $1173-1373 \mathrm{~K}$.

\section{Transpiration Measurements of Pu and Am Oxyhydroxide Volatilities:}

The apparatus used for the Pu and Am oxyhydroxide volatilities was the same as that for the $\mathrm{WO}_{2}(\mathrm{OH})_{2}(\mathrm{~g})$ runs, and experimental procedures were generally the same, except that the volatility determinations were done by collection and analysis of the $\mathrm{Pu}$ and Am carryover rather than by weight loss. The availability of analytic support time was limited during the course of this work, so priorities had to be set on the samples that were analyzed, and some runs therefore were not analyzed. Run parameters and 
Table 1. Transpiration data on volatility of $\mathrm{WO}_{2}(\mathrm{OH})_{2}(\mathrm{~g})$ based on the reaction: $\mathrm{WO}_{3}(\mathrm{~s})+\mathrm{H}_{2} \mathrm{O}(\mathrm{g})=\mathrm{WO}_{2}(\mathrm{OH})_{2}(\mathrm{~g})$.

\begin{tabular}{|c|c|c|c|c|c|c|c|c|c|}
\hline \multirow{2}{*}{$\begin{array}{l}\mathrm{T} \\
\mathrm{K}\end{array}$} & \multirow{2}{*}{$\begin{array}{l}\text { time, } \\
\text { min }\end{array}$} & \multirow{2}{*}{$\begin{array}{c}\mathrm{cm}^{3} / \mathrm{min} \\
\mathrm{Ar}\end{array}$} & \multirow{2}{*}{$\begin{array}{c}\mathrm{g} \\
\mathrm{H}_{2} \mathrm{O}\end{array}$} & \multirow{2}{*}{$\begin{array}{c}\text { moles } \\
\mathrm{Ar}\end{array}$} & \multirow{2}{*}{$\begin{array}{l}\text { moles } \\
\mathrm{H}_{2} \mathrm{O}\end{array}$} & \multirow{2}{*}{$\begin{array}{l}\mathrm{pH}_{2} \mathrm{O}, \\
\text { atm }\end{array}$} & \multirow{2}{*}{$\begin{array}{l}\mathrm{WO}_{3} \mathrm{wt} . \\
\text { loss, mg }\end{array}$} & \multicolumn{2}{|c|}{$\mathrm{pWO}_{2}(\mathrm{OH})_{2}$ atm } \\
\hline & & & & & & & & meas. & liter.[9] \\
\hline $1323^{a}$ & 60 & 200 & 6.03 & 0.497 & 0.335 & 0.402 & 141.1 & $7.3 \times 10^{-4}$ & $11.0 \times 10^{-4}$ \\
\hline 1319 & 60 & 100 & 2.69 & 0.248 & 0.149 & 0.376 & 45.4 & $4.9 \times 10^{-4}$ & $9.8 \times 10^{-4}$ \\
\hline 1319 & 60 & 100 & 2.91 & 0.248 & 0.162 & 0.395 & 52.6 & $5.5 \times 10^{-4}$ & $10.3 \times 10^{-4}$ \\
\hline 1319 & 60 & 50 & 1.70 & 0.124 & 0.094 & 0.432 & 47.2 & $9.3 \times 10^{-4}$ & $11.2 \times 10^{-4}$ \\
\hline 1317 & 30 & 25 & 0.97 & 0.093 & 0.054 & 0.367 & 35.4 & $10.4 \times 10^{-4}$ & $9.3 \times 10^{-4}$ \\
\hline $1322^{b}$ & 60 & 50 & 1.52 & 0.124 & 0.084 & 0.405 & 40.7 & $8.4 \times 10^{-4}$ & $10.9 \times 10^{-4}$ \\
\hline
\end{tabular}

a This run was carried out in a separate furnace than used for the work in the Pu Facility. The furnace tube used had an inner diameter of $30 \mathrm{~mm}$ compared with $22 \mathrm{~mm}$ for the other runs.

b $\mathrm{Al}_{2} \mathrm{O}_{3}$ wool plugs were used on either side of the boat in this run.

volatility results for runs with completed analyses are summarized in Tables 2 and 3. A $0.56 \mathrm{~g}$ sample of $239 \mathrm{PuO}_{2}$ was used in runs 2 to 21 , and was contained in an $\mathrm{Al}_{2} \mathrm{O}_{3}$ combustion boat (from Alfa Products), $2.3 \mathrm{~cm}$ wide $\times 5.8 \mathrm{~cm}$ long $\times 1.3 \mathrm{~cm}$ high. A 0.96 g sample of $\mathrm{PuO}_{2} / 2 \% \mathrm{AmO}_{2}$ was used in runs 23 to 44 and was contained in an $\mathrm{Al}_{2} \mathrm{O}_{3}$ combustion boat (from Atomergic), $1.7 \mathrm{~cm}$ wide $\times 5.0 \mathrm{~cm}$ long $\times 0.7 \mathrm{~cm}$ high.

Water transport that was determined by weight gain of Drierite was consistent with water bath temperatures and carrier gas flow rates for flow rates of 50-100 $\mathrm{cm}^{3} / \mathrm{min}$. At the higher gas flow rates of $500-1000 \mathrm{~cm} 3 / \mathrm{min}$, physical carrying of water also occurred from the water bath, and reduced water bath temperatures had to be used to maintain the desired amounts of water vapor flow. In all cases the amount of water picked up by the Drierite was used to determine the amount of water carried.

Temperature profiles were taken of the furnace hot zone, and showed the central uniform temperature hot zone (to within $10^{\circ} \mathrm{C}$ ) was $7 \mathrm{~cm}$ long at $1050^{\circ} \mathrm{C}$ and 5 $\mathrm{cm}$ long at $1150^{\circ} \mathrm{C}$, with a dropoff of $100 \mathrm{~K}$ in $5 \mathrm{~cm}$ on each side of the hot zone at each temperature. Because of the shortness of the hot zone and in order to leave room to maintain a dust filter, the center of the boat was displaced $1.3 \mathrm{~cm}$ upstream of the center of the hot zone. The purpose of the dust filter was to stop any fine particulates swept by the gas flow while allowing volatilized $\mathrm{Pu}$ and Am oxyhydroxides to pass through. $\mathrm{Al}_{2} \mathrm{O}_{3}$ wool or $\mathrm{SiO}_{2}$ glass wool located downstream of the dust filter was used to condense out the Pu or Am oxyhydroxides. We expect the volatilities of $\mathrm{Pu}$ and Am oxyhydroxicies to decrease by about a factor of 5 with a $100 \mathrm{~K}$ decrease in temperature, so that a length of $5 \mathrm{~cm}$ of wool should condense out about $80 \%$ each of the $\mathrm{Pu}$ and Am oxyhydroxides. Additional experimental details are given in the Appendix. This includes details on the arrangements of wool filters and collectors used in the various runs, analysis techniques, diagnostics on dust transport and on wall deposits, and sintering effects in the samples. 


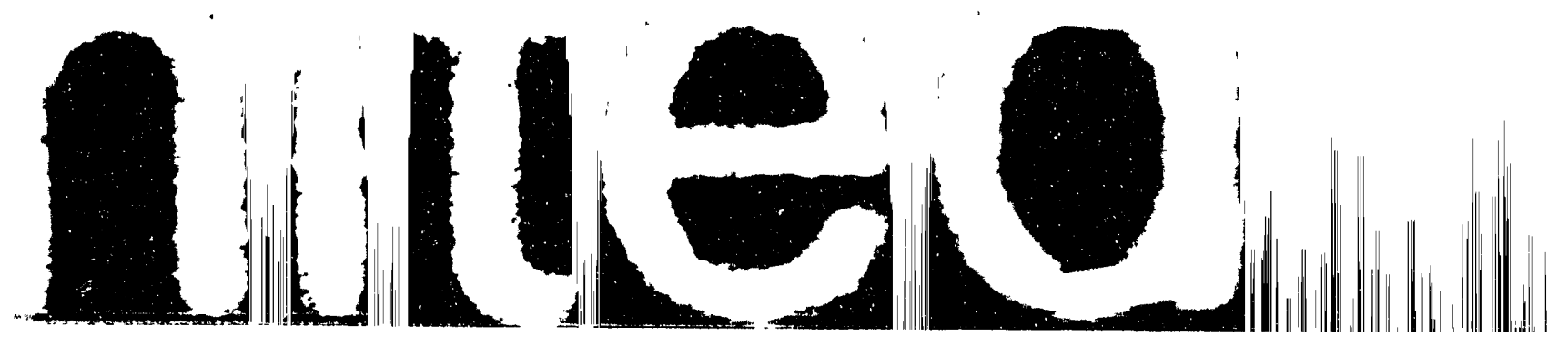

Table 2. Summary of conditions of run time and gas flow for $\mathrm{PuO}_{2}(\mathrm{~s})$ and $\mathrm{PuO}_{2} / 2 \% \mathrm{AmO}_{2}$ (s) transpiration runs. Runs \#2-21 are for $239 \mathrm{PuO}_{2}$ (s), runs \#23-44 are for $239 \mathrm{PuO}_{2} / 2 \% 241 \mathrm{AmO}_{2}(\mathrm{~s})$, and run \#73 is for 238 $\mathrm{PuO}_{2}$.

\begin{tabular}{|c|c|c|c|c|c|c|c|c|}
\hline \multirow{2}{*}{$\begin{array}{l}\text { run } \\
\#\end{array}$} & \multirow{2}{*}{$\begin{array}{l}\text { time, } \\
\min \end{array}$} & \multirow{2}{*}{$\begin{array}{c}\mathrm{cm}^{3} / \min \\
\mathrm{O}_{2}\end{array}$} & \multirow{2}{*}{$\mathrm{cm}^{3 / m i n}$} & \multirow{2}{*}{$\stackrel{\mathrm{g}}{\mathrm{H}_{2} \mathrm{O}}$} & \multicolumn{3}{|c|}{ moles of gas passed } & \multirow{2}{*}{$\begin{array}{c}\text { total mole } \\
\text { of gas }\end{array}$} \\
\hline & & & & & $\mathrm{O}_{2}$ & $\mathrm{Ar}$ & $\mathrm{H}_{2} \mathrm{O}$ & \\
\hline 2 & 120 & 500 & 500 & 42.31 & 2.479 & 2.479 & 2.349 & 7.307 \\
\hline 4 & 120 & 250 & 250 & 9.07 & 1.239 & 1.239 & 0.503 & 2.981 \\
\hline 5 & 60 & 250 & 250 & 4.49 & 0.620 & 0.620 & 0.249 & 1.489 \\
\hline 6 & 60 & 250 & 250 & 2.01 & 0.620 & 0.620 & 0.112 & 1.352 \\
\hline 8 & 60 & 250 & 250 & 2.26 & 0.620 & 0.620 & 0.125 & 1.365 \\
\hline 9 & 120 & 500 & & 4.48 & 2.479 & & 0.249 & 2.728 \\
\hline 11 & 120 & 500 & & 3.90 & 2.479 & & 0.217 & 2.696 \\
\hline 19 & 240 & 500 & & 8.43 & 4.957 & & 0.468 & 5.425 \\
\hline 20 & 120 & 500 & & 4.05 & 2.479 & & 0.225 & 2.704 \\
\hline 21 & 65 & 500 & & 2.20 & 1.343 & & 0.122 & 1.465 \\
\hline 23 & 250 & 500 & & 8.58 & 5.164 & & 0.476 & 5.640 \\
\hline 24 & 125 & 500 & & 4.20 & 2.582 & & 0.233 & 2.815 \\
\hline 25 & 65 & 500 & & 2.15 & 1.343 & & 0.119 & 1.462 \\
\hline 28 & 125 & 1000 & & & 5.164 & & & 5.164 \\
\hline 32 & 300 & 100 & & 18.90 & 1.239 & & 1.049 & 2.288 \\
\hline 33 & 180 & 50 & & 6.10 & 0.372 & & 0.339 & 0.711 \\
\hline 34 & 300 & 50 & & 13.87 & 0.620 & & 0.770 & 1.390 \\
\hline 36 & 600 & 50 & & 33.95 & 1.239 & & 1.885 & 3.124 \\
\hline 37 & 600 & 50 & & 27.84 & 1.239 & & 1.545 & 2.784 \\
\hline 44 & 600 & 50 & & 22.38 & 1.239 & & 1.242 & 2.481 \\
\hline 73 & 900 & 50 & & 30.09 & 1.859 & & 1.670 & 3.529 \\
\hline
\end{tabular}


Table 3. Summary of run temperatures, pressures of $\mathrm{O}_{2}(\mathrm{~g})$ and $\mathrm{H}_{2} \mathrm{O}(\mathrm{g})$, collecied amounts of $\mathrm{Pu}$ and $\mathrm{Am}$, and derived pressures of $\mathrm{PuO}_{2}(\mathrm{OH})_{2}(\mathrm{~g})$ and $\mathrm{AmO}_{2}(\mathrm{OH})_{2}(\mathrm{~g})$ for $\mathrm{PuO}_{2}(\mathrm{~s})$ and $\mathrm{PuO}_{2} / 2 \% \mathrm{AmO}_{2}$ (s) transpiration runs. Runs \#2-21 are for $239 \mathrm{PuO}_{2}(\mathrm{~s})$, runs \#23-44 are for $239 \mathrm{PuO}_{2} / 2 \%$ $241 \mathrm{AmO}_{2}$ (s) and run \#73 is for $238 \mathrm{PuO}_{2}$.

\begin{tabular}{|c|c|c|c|c|c|c|c|}
\hline $\begin{array}{l}\text { run } \\
\#\end{array}$ & $\begin{array}{l}\mathrm{T}, \\
\mathrm{K}\end{array}$ & $\begin{array}{l}\mathrm{pO}_{2} \\
\mathrm{~atm}\end{array}$ & $\begin{array}{l}\mathrm{pH}_{2} \mathrm{O} \\
\text { atm }\end{array}$ & $\begin{array}{l}\mu g \\
\mathrm{Pu}\end{array}$ & $\begin{array}{l}\mu g \\
\text { Am }\end{array}$ & $\underset{\mathrm{atm}}{\mathrm{pPuO}_{2}(\mathrm{OH})_{2}}$ & $\begin{array}{c}\mathrm{pAmO}_{2}(\mathrm{OH})_{2} \\
\mathrm{~atm}\end{array}$ \\
\hline 2 & 1322 & 0.339 & 0.321 & $14.2^{a}$ & $0.0075^{a}$ & & \\
\hline 4 & 1314 & 0.416 & 0.169 & 0.22 & & $3.09 \times 10^{-10}$ & \\
\hline 5 & 1413 & 0.416 & 0.167 & 24.9 & & $7.00 \times 10^{-8}$ & \\
\hline 6 & 1414 & 0.459 & 0.0828 & 0.975 & & $3.02 \times 10^{-9}$ & \\
\hline 8 & 1413 & 0.454 & 0.0916 & 1.3 & & $3.98 \times 10^{-9}$ & \\
\hline 9 & 1316 & 0.909 & 0.0913 & 0.26 & & $3.99 \times 10^{-10}$ & \\
\hline 11 & 811 & 0.920 & 0.0804 & 0.02 & & $3.10 \times 10^{-11}$ & \\
\hline 19 & 1216 & 0.914 & 0.0863 & 0.02 & & $1.54 \times 10^{-11}$ & \\
\hline 20 & 1347 & 0.917 & 0.0832 & 0.04 & & $6.19 \times 10^{-11}$ & \\
\hline 21 & 1415 & 0.917 & 0.0828 & 0.01 & & $2.86 \times 10^{-11}$ & \\
\hline 23 & 1218 & 0.916 & 0.0844 & 0.178 & 0.016 & $1.32 \times 10^{-10}$ & $1.2 \times 10^{-11}$ \\
\hline 24 & 1331 & 0.917 & 0.0828 & 0.247 & 0.003 & $3.67 \times 10^{-10}$ & $4.4 \times 10^{-12}$ \\
\hline 25 & 1433 & 0.919 & 0.0814 & 0.089 & 0.003 & $2.55 \times 10^{-10}$ & $8.5 \times 10^{-12}$ \\
\hline 28 & 1432 & 1.000 & & 0.09 & 0.002 & $7.29 \times 10^{-11}$ & $1.6 \times 10^{-12}$ \\
\hline 32 & 1434 & 0.542 & 0.458 & 0.037 & 0.001 & $6.77 \times 10^{-11}$ & $1.8 \times 10^{-12}$ \\
\hline 33 & 1434 & 0.523 & 0.477 & 0.214 & 0.004 & $1.26 \times 10^{-9}$ & $2.3 \times 10^{-11}$ \\
\hline 34 & 1334 & 0.446 & 0.554 & 0.091 & 0.001 & $2.44 \times 10^{-10}$ & $3.0 \times 10^{-12}$ \\
\hline 36 & 1229 & 0.397 & 0.603 & 0.177 & $<0.001$ & $2.37 \times 10^{-10}$ & $<1.3 \times 10^{-12}$ \\
\hline 37 & 825 & 0.445 & 0.555 & 0.073 & $<0.001$ & $1.10 \times 10^{-10}$ & $<1.5 \times 10^{-12}$ \\
\hline 44 & 1431 & 0.499 & 0.501 & 0.44 & 0.0088 & $7.42 \times 10^{-10}$ & $1.5 \times 10^{-11}$ \\
\hline 73 & 823 & 0.527 & 0.473 & 0.0032 & & $3.86 \times 10^{-12}$ & \\
\hline
\end{tabular}

aAnalysis of Pu and Am present on dust filter.

Analysis of Results:

We found as these experiments got underway that the $\mathrm{Pu}$ volatilities were considerably lower than we had predicted $[2,3]$ (see Fig. 2). This presented us with difficulties in obtaining accurate volatility values. We reject run \#5 because of background contamination. In runs \#4,6, and 8 , where high gas flow rates and a fine particulate sample were used, some dust transport of $\mathrm{PuO}_{2}$ may have occurred that contributed to the collected sample. These volatilities may therefore be somewhat high. Extensive sintering had occurred in the source samples used in runs $\# 19,20$, 21 , and 32 , thus greatly reducing the sample surface area and making it difficult to 
obtain equilibration between the carrier gas and the sample. We therefore reject these runs. Runs \#25, 33, 34, and 44 also showed evidence for sintering effects and these volatilities appear to be on the low side. Some cross contamination may have also occurred because we reused the same furnace tubes for most of the runs, hence increasing uncertainties in the results. We consider runs \#11, 37 and 73 that were run at $\sim 820 \mathrm{~K}$ to provide only an upper bound to the volatilities, and give a representation of the level of contamination to be expected in handling the collection samples in the glovebox. Considering the various uncertainties in the selected runs, we estimate that the volatility values fall within the range of $1 / 3$ to 3 times the measured values.

We treat the thermodynamics as follows. We take the plutonium volatilization to proceed by the reaction,

$$
\mathrm{PuO}_{2}(\mathrm{~s})+1 / 2 \mathrm{O}_{2}(\mathrm{~g})+\mathrm{H}_{2} \mathrm{O}(\mathrm{g})=\mathrm{PuO}_{2}(\mathrm{OH})_{2}(\mathrm{~g}) \text {. }
$$

The equilibrium constant for this reaction, $\mathrm{K}_{\mathrm{eq}}$, is given by,

$$
\mathrm{K}_{\mathrm{eq}}=\left[\mathrm{pPuO}_{2}(\mathrm{OH})_{2}\right] /\left[\mathrm{aPuO}_{2}\right]\left[\mathrm{pO}_{2}\right]^{1 / 2}\left[\mathrm{pH}_{2} \mathrm{O}\right],
$$

where $p$ indicates partial pressures of the gaseous species in atm and a the activity of the solid phase. Taking the activity of $\mathrm{PuO}_{2}(\mathrm{~s})$ to be unity, and using the partial pressures for $\mathrm{O}_{2}(\mathrm{~g}), \mathrm{H}_{2} \mathrm{O}(\mathrm{g})$, and $\mathrm{PuO}_{2}(\mathrm{OH})_{2}(\mathrm{~g})$ from Table 3, we obtain $\mathrm{K}_{\text {eq }}$ values for reaction (2). We make a second-law of thermodynamics plot of log $\mathrm{K}_{\mathrm{eq}}$ versus inverse temperature (see Fig. 2), which should give a linear slope. However, the scatter in the data is too large to obtain a meaningful slope by the second law method. We proceed to analyze the data using the third-law method. The standard free energy change for reaction (2), $\Delta G^{\circ} \mathrm{T}$, based on the relation $\Delta G^{\circ} \mathrm{T}=-R T \ln \mathrm{K}_{\text {eq }}$, is given in Table 5 for the selected experimental points. The change in free energy function for reaction (2), $\left(\Delta \mathrm{GO}^{\circ} \mathrm{T}-\Delta \mathrm{H}^{\circ}{ }_{298}\right) / \mathrm{T}$, is obtained using available free energy function data on $\mathrm{PuO}_{2}$ (s) from Cordfunke et al.[15], data for $\mathrm{O}_{2}(\mathrm{~g})$ and $\mathrm{H}_{2} \mathrm{O}(\mathrm{g})$ from JANAF [9], and estimated data for $\mathrm{PuO}_{2}(\mathrm{OH})_{2}(\mathrm{~g})$ from Krikorian [2]. The estimated free energy function for $\mathrm{PuO}_{2}(\mathrm{OH})_{2}(\mathrm{~g})$ is given by Krikorian as

$$
\begin{aligned}
& -\left(G^{\circ} T-H_{2}{ }_{298}\right) / T=S^{\circ}{ }_{298}\left[1+(0.88+0.20 x+0.57 y)(T-298.15)\left(10^{-4}\right)\right], \\
& \text { where } S^{0} 298=108.8+25.1 \ln \left(A_{M}\right)+20.9 x+41.8 y .
\end{aligned}
$$

Units of $-\left(\mathrm{G}^{\circ} \mathrm{T}-\mathrm{H}^{\circ}{ }_{298}\right) / \mathrm{T}$ are in $\mathrm{J} / \mathrm{mol}-\mathrm{K}, \mathrm{x}$ and $\mathrm{y}$ are the coefficients for $\mathrm{O}$ and $\mathrm{OH}$ in the formula $M O_{x}(O H)_{y}$ and $A_{M}$ is the atomic weight of the central atom $M$. The $\left(\Delta G{ }^{\circ} T\right.$ $\Delta \mathrm{H}^{\circ}{ }_{298} / T$ values are given in Table 4 for the experimental points, and are also summarized in Table 5 over a wide temperature range. By appropriately combining 


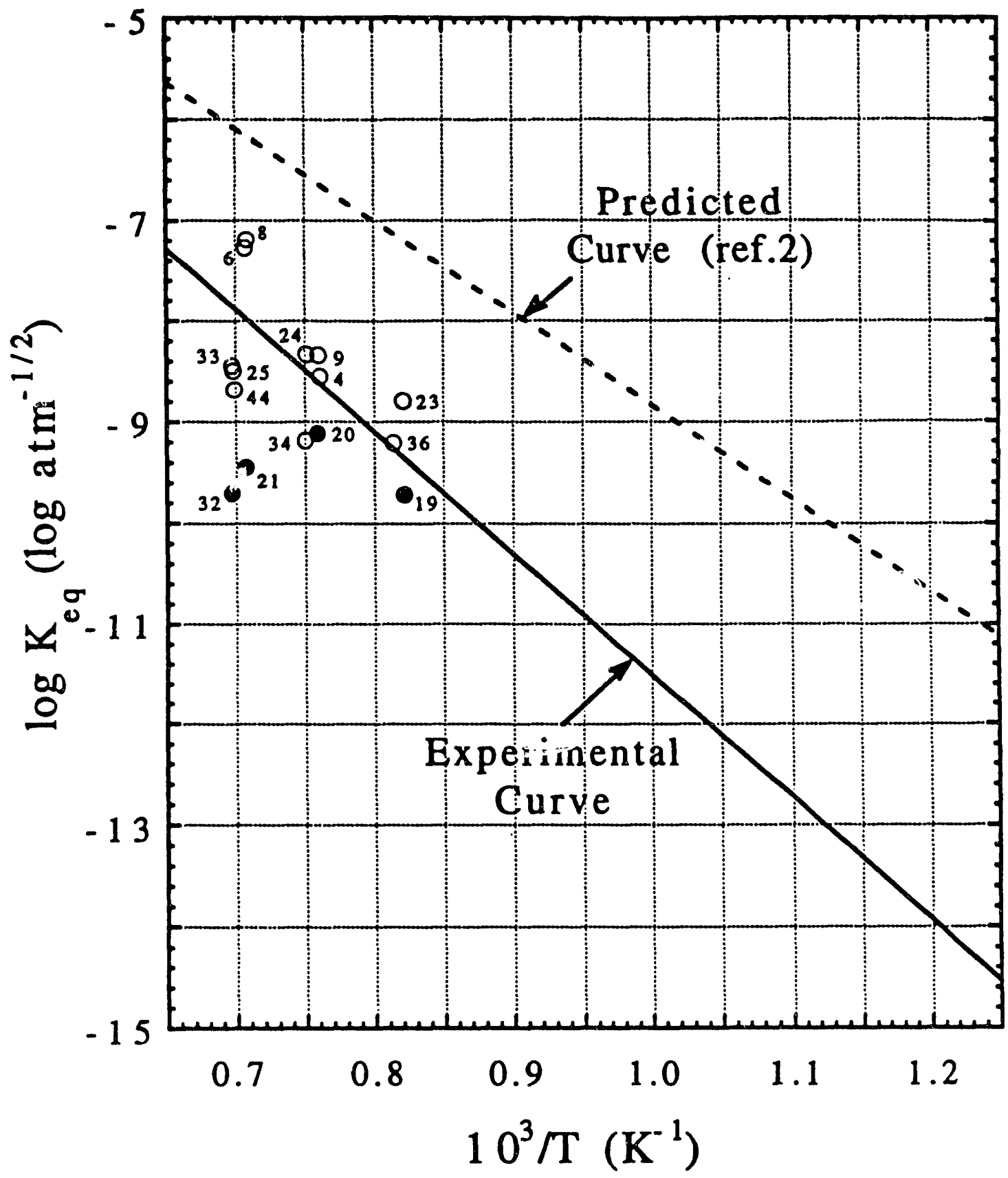

Fig. 2. Plot of $\log \mathrm{K}_{\mathrm{eg}}$ versus inverse temperature for the reaction $\mathrm{PuO}_{2}(\mathrm{~s})+1 / 2 \mathrm{O}_{2}(\mathrm{~g})$ $+\mathrm{H}_{2} \mathrm{O}(\mathrm{g})=\mathrm{PuO}_{2}(\mathrm{OH})_{2}(\mathrm{~g})$. Experimental data points are indicated by circles with adjacent run numbers. Darkened circles show data points that are rejected because extensive sintering in the sample prevented equilibration. The experimental curve represents a third-law analysis of the data. An earlier theoretical prediction curve is also given. 
the $\Delta G^{\circ} \mathrm{T}$ and $\left(\Delta \mathrm{GO}^{\circ} \mathrm{T}-\Delta \mathrm{H}^{\circ} 298\right) / \mathrm{T}$ values, we obtain $\Delta \mathrm{H}^{\circ}{ }_{298}$ values for each of the data points (see Table 4). The average value of $\Delta \mathrm{H}^{\circ} 298$ is $232.43 \mathrm{~kJ} / \mathrm{mol}$ with a standard deviation of $\pm 15.85 \mathrm{~kJ} / \mathrm{mol}$. Using this value of $\Delta \mathrm{H}^{\circ}{ }_{298}$ together with the free energy functions in 7 able 5 , we can calculate values for $\Delta \mathrm{G}^{\circ} \mathrm{T}$ and $\log \mathrm{K}_{\mathrm{eq}}$ at various temperatures. These are expressed analytically by the following approximate relationships:

$$
\begin{aligned}
& \Delta G^{\circ} \mathrm{T}=231.3-0.0109 \mathrm{~T}, \mathrm{~kJ} / \mathrm{mol}, \\
& \log \mathrm{K}_{\mathrm{eq}}=-12,080 / \mathrm{T}+0.569, \log \mathrm{atm}^{-1 / 2}
\end{aligned}
$$

The fit of equation (9) to the experimental data is illustrated in Fig. 2.

For americium volatilization, we express the reaction as

$$
\left.\mathrm{AmO}_{2} \text { (s.s. in } \mathrm{PuO}_{2}, \mathrm{a}=0.021\right)+1 / 2 \mathrm{O}_{2}(\mathrm{~g})+\mathrm{H}_{2} \mathrm{O}(\mathrm{g})=\mathrm{AmO}_{2}(\mathrm{OH})_{2}(\mathrm{~g}) \text {, }
$$

where $\mathrm{AmO}_{2}$ is present in solid solution in $\mathrm{PuO}_{2}$ (s). Assuming the $\mathrm{AmO}_{2}$ to form an ideal solution, we take the activity of $\mathrm{AmO}_{2}$ to be equal to the mole fraction, or 0.021 . The equilibrium constant for reaction (10) is given by

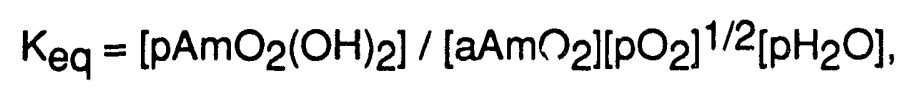

where a $\mathrm{AmO}_{2}$ is taken as 0.021 in our experiments. To calculate $\mathrm{Keq}$ values, we review the Am volatility data (see Table 3 ). Because the Am values are near the limits of detection, we find it convenient to compare the ratios of Pu/Am in the volatilized samples with that in the starting material (see Table 6). The ratio of Pu/Am in the starting material is 47.6. In run \#23, the first run made with the $\mathrm{PuO}_{2} / 2 \% \mathrm{AmO}_{2}$ sample, Am is enriched by about a factor of 4 in the volatilized material with a Pu/Am ratio of 11 . In subsequent runs, the Pu/Am ratio in the volatilized material is about equal to or greater than in the starting materis.l. This suggests that the Am volatility may have been high in the initial run but may have been limited by surface depletion of the $\mathrm{AmO}_{2}$ concentration in subsequent runs. In Table 6, where temperatures for the various runs are shown in addition to the Pu/Am ratios, we see that for the runs made at $\sim 1430 \mathrm{~K}$, the Pu/Am ratios for the volatilized material are in the range of 30-54, while at $\sim 1330 \mathrm{~K}$, the ratios are $\sim 80$, ard at $1229 \mathrm{~K}$, the ratio is $>177$. This indicates that the replenishment of the $\mathrm{AmO}_{\hat{L}}$ concentration at the sample surface is controlled by a diffusional process, with the closest approach to equilibrium in the runs at the highest temperatures, $\sim 1430 \mathrm{~K}$, except for the initial run. Recognizing that the $\mathrm{AmO}_{2}(\mathrm{OH})_{2}$ volatilities are likely on the low side, we proceed to calculate equilibrium constants for reaction (10). We reject run $\# 32$ because of high sintering in the sample. Also, run \#28 can not be used because it did not have water vapor present, and runs \#36 and 37 showed no detectable Am volatility. $\mathrm{Keq}$ values for the remaining runs are summarized in Table 7. We proceed with a third law analysis of the data (Table 7) by taking the $\left(\Delta \mathrm{GO}_{\mathrm{T}} \mathrm{T}-\Delta \mathrm{HO}_{2}{ }_{298}\right) / \mathrm{T}$ values for the $\mathrm{AmO}_{2}(\mathrm{OH})_{2}$ volatilization reaction 
Table 4. Summary of thermodynamic data for the reaction $\mathrm{PuO}_{2}(s)+1 / 2$ $\mathrm{O}_{2}(\mathrm{~g})+\mathrm{H}_{2} \mathrm{O}(\mathrm{g})=\mathrm{PuO}_{2}(\mathrm{OH})_{2}(\mathrm{~g})$, based on the experimental results.

\begin{tabular}{|c|c|c|c|c|c|}
\hline $\begin{array}{l}\text { run } \\
\#\end{array}$ & $\begin{array}{l}\mathrm{T} \\
\mathrm{K}\end{array}$ & $\begin{array}{l}\mathrm{K}_{\mathrm{eq}} \\
\mathrm{atm}^{-1 / 2}\end{array}$ & $\begin{array}{l}\Delta \mathrm{G}^{0} \mathrm{~T} \\
\mathrm{~kJ} / \mathrm{mol}\end{array}$ & $\begin{array}{c}\left(\Delta \mathrm{G}^{0} \mathrm{~T}-\Delta \mathrm{H}^{\mathrm{O}_{298}}\right) / \mathrm{T} \\
\mathrm{J} / \mathrm{mol}-\mathrm{K}\end{array}$ & $\begin{array}{c}\Delta \mathrm{H}^{\mathrm{O}} 298, \\
\mathrm{~kJ} / \mathrm{mol}\end{array}$ \\
\hline 4 & 1312 & $2.84 \times 10^{-9}$ & 214.67 & -11.12 & 229.30 \\
\hline 6 & 1414 & $5.38 \times 10^{-8}$ & 196.64 & -11.86 & 213.41 \\
\hline 8 & 1413 & $6.45 \times 10^{-8}$ & 194.51 & -11.85 & 211.26 \\
\hline 9 & 1316 & $4.58 \times 10^{-9}$ & 210.10 & -11.14 & 224.76 \\
\hline 23 & 1218 & $1.64 \times 10^{-9}$ & $204.3 L$ & -10.77 & 217.50 \\
\hline 24 & 1331 & $4.63 \times 10^{-9}$ & 212.37 & -11.25 & 227.34 \\
\hline 25 & 1433 & $3.27 \times 10^{-9}$ & 232.79 & -12.06 & 250.07 \\
\hline 33 & 1434 & $3.65 \times 10^{-9}$ & 231.64 & .07 & 248.95 \\
\hline 34 & 1334 & $6.59 \times 10^{-10}$ & 234.30 & -11.27 & 249.33 \\
\hline 36 & 1229 & $6.24 \times 10^{-10}$ & 216.58 & -10.81 & 229.86 \\
\hline \multirow[t]{2}{*}{44} & 1431 & $2.10 \times 10^{-9}$ & 237.73 & -12.04 & 254.96 \\
\hline & & & & \multicolumn{2}{|c|}{$\begin{array}{r}\text { ave. } 232.43 \\
\text { std. dev. } \pm 15.85\end{array}$} \\
\hline
\end{tabular}

Table 5. Summary of free energy function values for the reaction $\mathrm{PuO}_{2}(\mathrm{~s})+1 / 2 \mathrm{O}_{2}(\mathrm{~g})+\mathrm{H}_{2} \mathrm{O}(\mathrm{g})=\mathrm{PuO}_{2}(\mathrm{OH})_{2}(\mathrm{~g})$.

\begin{tabular}{|c|c|c|c|c|c|}
\hline \multirow{2}{*}{$\begin{array}{l}\mathrm{T} \\
\mathrm{K}\end{array}$} & \multicolumn{4}{|c|}{ 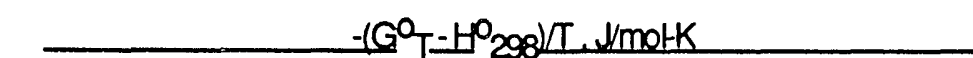 } & \multirow{2}{*}{$\underset{\mathrm{J} / \mathrm{mol}-\mathrm{K}}{\left(\Delta \mathrm{G}^{\circ} \mathrm{T}-\Delta \mathrm{H}^{\circ}{ }_{298}\right) / \mathrm{T}}$} \\
\hline & $\mathrm{PuO}_{2}(\mathrm{~s})$ & $1 / 2 \mathrm{O}_{2}(g)$ & $\mathrm{H}_{2} \mathrm{O}(\mathrm{g})$ & $\mathrm{PuO}_{2}(\mathrm{OH})_{2}(\mathrm{~g})$ & \\
\hline 700 & 87.413 & 106.806 & 198.465 & 407.807 & -15.123 \\
\hline 800 & 93.946 & 108.063 & 201.322 & 416.801 & -13.470 \\
\hline 900 & 100.275 & 109.276 & 204.084 & 425.795 & -12.160 \\
\hline 1000 & 106.354 & 110.438 & 206.738 & 434.789 & -11.259 \\
\hline 1100 & 112.170 & 111.546 & 209.285 & 443.784 & -10.783 \\
\hline 1200 & 117.730 & 112.604 & 211.730 & 452.778 & -10.714 \\
\hline 1300 & 123.043 & 113.614 & 214.080 & 461.772 & -11.035 \\
\hline 1400 & 128.127 & 114.579 & 216.341 & 470.766 & -11.719 \\
\hline 1500 & 132.996 & 115.501 & 218.520 & 479.761 & -12.744 \\
\hline
\end{tabular}


Table 6. Pu/Am ratios found in volatilized samples for runs at various temperatures. The Pu/Am ratio in the starting material was 47.6.

\begin{tabular}{ccc}
\hline Run \# & $\mathrm{T}, \mathrm{K}$ & $\begin{array}{l}\mu \mathrm{g} \text { Pu/ } \mathrm{gg} \text { Am, in } \\
\text { volatilized material }\end{array}$ \\
\hline 23 & 1218 & 11 \\
24 & 1331 & 82 \\
25 & 1433 & 30 \\
28 & 1432 & 45 \\
32 & 1434 & 37 \\
33 & 1434 & 54 \\
34 & 1334 & 81 \\
36 & 1229 & $>177$ \\
37 & 825 & $>73$ \\
44 & 1431 & 50 \\
\hline
\end{tabular}

(reaction (10)), to be identical to those for $\mathrm{PuO}_{2}(\mathrm{OH})_{2}$ volatilization reaction (reaction (2)), as given in Table 5. We obtain an average $\Delta \mathrm{H}^{0} 298$ of $240.5 \mathrm{~kJ} / \mathrm{mol}$ with a standard deviation of $20.0 \mathrm{~kJ} / \mathrm{mol}$ for reaction (10). We prefer to give greater weight to run \#23, and therefore take $\Delta \mathrm{H}^{\circ} 298$ to be $225 \mathrm{~kJ} / \mathrm{mol}$ with an estimated uncertainty of $\pm 30 \mathrm{~kJ} / \mathrm{mol}$. We then obtain the following analytical expressions for $\Delta \mathrm{G}^{\circ} \mathrm{T}$ and $\log _{\mathrm{Keq}}$ for reaction (10).

$$
\begin{aligned}
& { }^{\Delta \mathrm{GO}} \mathrm{T}=223.9-0.0109 \mathrm{~T}, \mathrm{~kJ} / \mathrm{mol}, \\
& \log \mathrm{K}_{\mathrm{eq}}=-11,695 / \mathrm{T}+0.571, \log \mathrm{atm}^{-1 / 2} .
\end{aligned}
$$

\section{Discussion}

The observed volatilities of Pu in these experiments were substantially lower than we had predicted (see Fig. 2). This reduced the accuracy with which we could determine the Pu volatilities. Th.e various problems encountered, i.e., background contamination, carrying of dust (at high flow rates), sintering of the sample, incomplete collection of the volatilized sample on the collection plugs, cross contamination between runs from reuse of the furnace tubes, have all been mentioned. We estimate the accuracy of the measured Pu equilibrium pressures to be within plus a factor of 3 to minus a factor of $1 / 3$ of the selected values. For the measurements on Am volatilities, the same uncertainties apply as for the Pu measurements, plus the uncertainty due to surface depletion. We estimate the accuracy of the measured Am equilibrium pressures to be accurate to within plus a factor of 15 to minus a factor of $1 / 15$ of the selected values. 
Table 7. Summary of thermodynamic data for the reaction $\mathrm{AmO}_{2}$ (s.s., a $=$ $0.021)+1 / 2 \mathrm{O}_{2}(\mathrm{~g})+\mathrm{H}_{2} \mathrm{O}(\mathrm{g})=\mathrm{AmO}_{2}(\mathrm{OH})_{2}(\mathrm{~g})$, based on the experimental results.

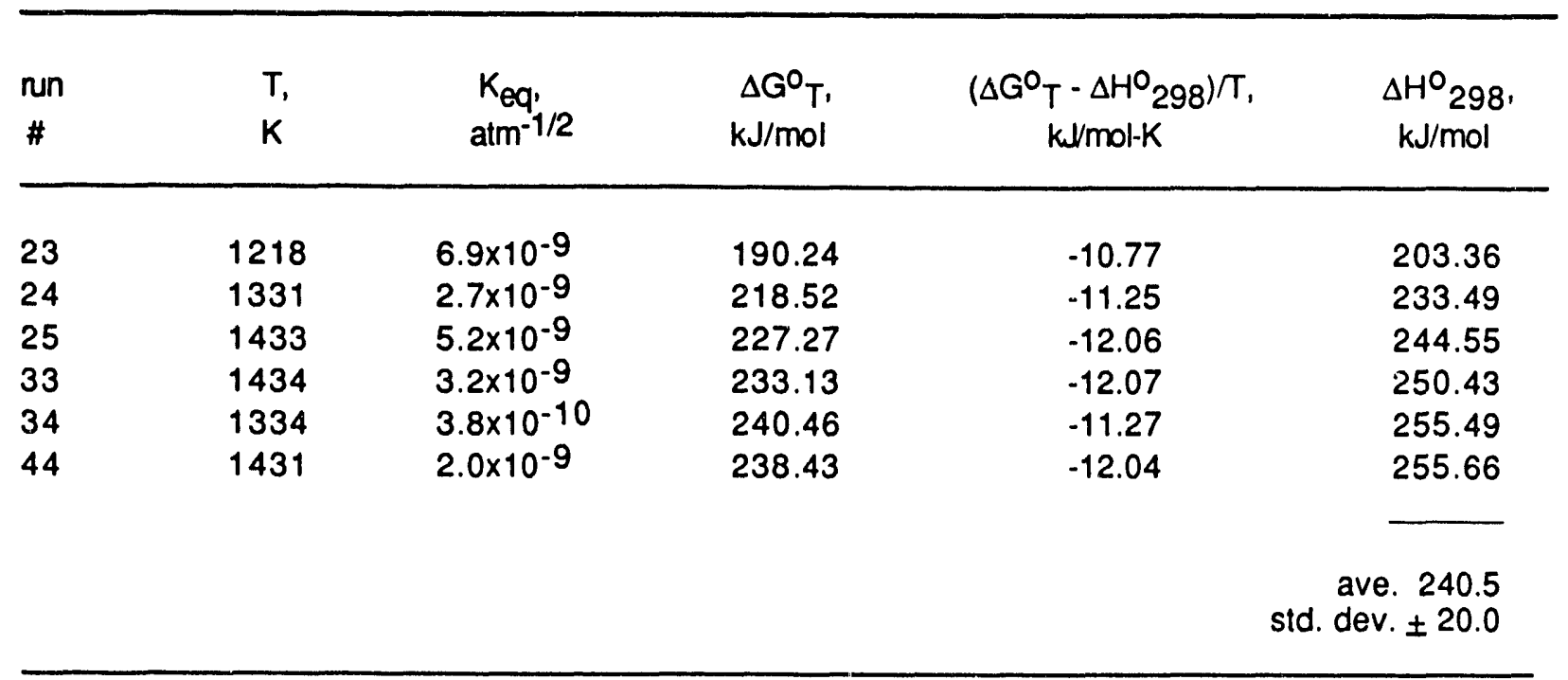

The experience gained here is useful in showing how improvements in accuracy of measuring Pu volatilities could be attained in future work. Using ${ }^{238} \mathrm{PuO}_{2}$ instead of ${ }^{239} \mathrm{PuO}_{2}$ as the sample material would improve the sensitivity of detection by alpha counting by about a factor of 275 because of the higher specific activity of $238 \mathrm{Pu}$. Temperatures could be held low enough to avoid sintering effects on equilibration, and collection tubes could be used instead of quartz wool to obtain more complete collection of the volatilized samples. This approach was used in one run, run \#73, at the end of this study.

Because of the low accuracy of measurement of Pu volatilities, we were not able to establish the formula of the volatilizing species through tests based on the variation of $\mathrm{O}_{2}$ and $\mathrm{H}_{2} \mathrm{O}$ pressures. We have assumed $\mathrm{PuO}_{2}(\mathrm{OH})_{2}(\mathrm{~g})$ to be the predominant volatilizing species based on estimated bond energy and entropy considerations of possible species, as discussed in ref. [2]. But, considering that the $\mathrm{PuO}_{2}(\mathrm{OH})_{2}(\mathrm{~g})$ volatility is lower than we had predicted, the next most likely species to consider that might make contributions to the volatility are $\mathrm{PuO}_{3}(\mathrm{~g})$ and $\mathrm{PuO}_{2} \mathrm{OH}(\mathrm{g})$. For example, in the analogous case for $\mathrm{U}, \mathrm{UO}_{3}(\mathrm{~g})$ is known to make a significant contribution to the volatility in addition to $\mathrm{UO}_{2}(\mathrm{OH})_{2}(\mathrm{~g})$ at temperatures in the vicinity of $1400 \mathrm{~K}$ [16], and in the analogous case for $\mathrm{Cr}$, volatilities of $\mathrm{CrO}_{3}(\mathrm{~g})$ and $\mathrm{CrO}_{2} \mathrm{OH}(\mathrm{g})$ are each an order of magnitude below that for $\mathrm{CrO}_{2}(\mathrm{OH})_{2}(\mathrm{~g})$ [17]. We find, however, that even if $\mathrm{PuO}_{3}(\mathrm{~g})$ or $\mathrm{PuO}_{2} \mathrm{OH}(\mathrm{g})$ are important at the temperature range of our measurements, $\sim 1400 \mathrm{~K}$, the dropoff in volatilities of $\mathrm{PuO}_{3}(\mathrm{~g})$ and $\mathrm{PuO} 2 \mathrm{OH}(\mathrm{g})$ with decreasing temperature would be much more rapid than for $\mathrm{PuO}_{2}(\mathrm{OH})_{2}(\mathrm{~g})$, so that $\mathrm{PuO}_{3}(\mathrm{~g})$ and $\mathrm{PuO}_{2} \mathrm{OH}(\mathrm{g})$ 
become unimportant at $823 \mathrm{~K}$ under the conditions of the Rocky Flats Plant incinerator. For example, let us assume that all of the experimentally observed Pu volatility is due to $\mathrm{PuO}_{3}(\mathrm{~g})$ according to the reaction,

$$
\mathrm{PuO}_{2}(\mathrm{~s})+1 / 2 \mathrm{O}_{2}(\mathrm{~g})=\mathrm{PuO}_{3}(\mathrm{~g}) \text {. }
$$

From the experimental data, we calculate appropriate values of $\mathrm{K}_{\mathrm{eq}}$ and $\Delta \mathrm{G}^{\circ} \mathrm{T}$. We use the same free energy function for $\mathrm{PuO}_{3}(\mathrm{~g})$ as for $\mathrm{UO}_{3}(\mathrm{~g})$ [15], and free energy functions for $\mathrm{PuO}_{2}(\mathrm{~s})$ from ref. [15] and for $\mathrm{O}_{2}(\mathrm{~g})$ from ref. [9], to obtain $\left(\Delta \mathrm{G}{ }^{\circ} \mathrm{T}\right.$ $\left.\Delta \mathrm{H}^{\circ} 298\right) / T$ values that range from $-146.63 \mathrm{~J} / \mathrm{mol}-\mathrm{K}$ at $800 \mathrm{~K}$ to $-136.99 \mathrm{~J} / \mathrm{mol}-\mathrm{K}$ at 1500 K. An average value of $\Delta \mathrm{HO}_{298}$ based on the experimental data is then calculated to be $423.7 \mathrm{~kJ} / \mathrm{mol}$ with a standard deviation of $18.5 \mathrm{~kJ} / \mathrm{mol}$. This leads to the expression

$$
\Delta \mathrm{GO}^{\mathrm{O}} \mathrm{T}=406.0-0.125 \mathrm{~T}, \mathrm{~kJ} / \mathrm{mol},
$$

for reaction (14). We then use this expression to calculate that in the presence of 0.1 atm $\mathrm{O}_{2}(\mathrm{~g})$, the assumed volatility of $\mathrm{PuO}_{3}(\mathrm{~g})$ would drop from $7.6 \times 10^{-10}$ atm at 1400 $\mathrm{K}$ to $1.8 \times 10^{-20} \mathrm{~atm}$ at $823 \mathrm{~K}$. Thus we see that even if $\mathrm{PuO}_{3}(\mathrm{~g})$ makes a significant contribution to the $\mathrm{Pu}$ volatility at $\sim 1400 \mathrm{~K}$, it drops to a negligible level relative to $\mathrm{PuO}_{2}(\mathrm{OH})_{2}(\mathrm{~g})$ at $823 \mathrm{~K}$. We can similarly show that $\mathrm{PuO}_{2} \mathrm{OH}(\mathrm{g})$ drops off to a negligible level at $823 \mathrm{~K}$. We conclude that although it has not been experimentally established that $\mathrm{P}_{1} \mathrm{O}_{2}(\mathrm{OH})_{2}(\mathrm{~g})$ is the species responsible for the volatilities observed in our experiments, other possible contributing species become of negligible importance under the Rocky Flats Plant incinerator conditions. Therefore, assuming all of the experimental volatility to result from $\mathrm{PuO}_{2}(\mathrm{OH})_{2}(\mathrm{~g})$ gives us a conservatively high value for $\mathrm{Pu}$ volatility under the Rocky Flats Plant incinerator conditions. We can make similar arguments to show that $\mathrm{AmO}_{2}(\mathrm{OH})_{2}(\mathrm{~g})$ is the dominant species under Rocky Flats Plant incinerator conditions.

We now proceed to calculate the $\mathrm{Pu}$ and $\mathrm{Am}$ volatilities produced in the secondary fluidized bed combustor of the Rocky Flats Plant incinerator. We take as operating conditions for the bed [18,19], a temperature of $823 \mathrm{~K}, 40 \mathrm{kmols} / \mathrm{h}$ of total gas flow at a pressure of $1 \mathrm{~atm}, 0.1 \mathrm{~atm} \mathrm{O}_{2}$, and 0.05 atm $\mathrm{H}_{2} \mathrm{O}$. We assume that $\mathrm{Pu}$ and $\mathrm{Am}$ are present in the bed in the form of $\mathrm{PuO}_{2}(\mathrm{~s})$ containing $200 \mathrm{ppm}$ of $\mathrm{AmO}_{2}$ in solid solution. (Note, however, that if insufficient $\mathrm{Pu}$ and Am are present in the waste to form a $\mathrm{PuO}_{2}$ (s) phase with dissolved $\mathrm{AmO}_{2}$ (s), then the volatilities of $\mathrm{Pu}$ and Am will be lower than calculated here.) We take 6000 hours of operating time per year. From equations (5) and (9), we obtain a $\mathrm{PuO}_{2}(\mathrm{OH})_{2}(\mathrm{~g})$ pressure of $1.2 \times 10^{-16}$ atm; and from equations (11) and (13), and using an activity of $2 \times 10^{-4}$ for $\mathrm{AmO}_{2}$, we obtain an $\mathrm{AmO}_{2}(\mathrm{OH})_{2}(\mathrm{~g})$ pressure of $7.3 \times 10^{-20} \mathrm{~atm}$. Taking the ratio of partial pressure of $\mathrm{PuO}_{2}(\mathrm{OH})_{2}$ to total gas pressure to be equal to the mole fraction of $\mathrm{PuO}_{2}(\mathrm{OH})_{2}$ in the gas, and multiplying this mole fraction by the molar flow rate of gas, we obtain a $\mathrm{PuO}_{2}(\mathrm{OH})_{2}(\mathrm{~g})$ transport rate of $4.9 \times 10^{-12}$ moles Pu/h, or $1.2 \times 10^{-9} \mathrm{~g} \mathrm{Pu} / \mathrm{h}$. At $6000 \mathrm{~h}$ of operation per year, this amounts to $7.1 \times 10^{-6} \mathrm{~g} \mathrm{Pu} / \mathrm{y}$. Similarly, for $\mathrm{AmO}_{2}(\mathrm{OH})_{2}(\mathrm{~g})$, 
we obtain a transport rate of $7.0 \times 10^{-13} \mathrm{~g} \mathrm{Am} / \mathrm{h}$ or $4.2 \times 10^{-9} \mathrm{~g} \mathrm{Am} / \mathrm{y}$. We need to assess the uncertainties in these values. For $\mathrm{PuO}_{2}(\mathrm{OH})_{2}(\mathrm{~g})$, a factor of 3 uncertainty on the high side results from the errors in the measured vapor pressures, and we add an additional factor of 5 uncertainty on the high side because of the error introduced from the estimated free energy function for $\mathrm{PuO}_{2}(\mathrm{OH})_{2}(\mathrm{~g})$. This gives a total esiimated error of a factor of 15 on the high side. For $\mathrm{AmO}_{2}(\mathrm{OH})_{2}(\mathrm{~g})$, the uncertainty is a factor of 15 on the high side from the measured vapor pressure and a factor of 5 on the high side from the estimated free energy function for a total estimated error of a factor of 75 on the high side. Taking the high side error estimates, the Pu transport rate becomes $1.8 \times 10^{-8} \mathrm{~g} \mathrm{Pu} / \mathrm{h}$ or $1.1 \times 10^{-4} \mathrm{~g}$ Pu/y, and the Am transport rate becomes $5.2 \times 10^{-11} \mathrm{~g}$ $\mathrm{Am} / \mathrm{h}$ or $3.1 \times 10^{-7} \mathrm{~g} \mathrm{Am} / \mathrm{y}$.

The thermodynamic data generated here on $\mathrm{PuO}_{2}(\mathrm{OH})_{2}(\mathrm{~g})$ and $\mathrm{AmO}_{2}(\mathrm{OH})_{2}(\mathrm{~g})$ can be applied to other mixed waste incinerators as well, to obtain equilibrium amounts of $\mathrm{PuO}_{2}(\mathrm{OH})_{2}(\mathrm{~g})$ and $\mathrm{AmO}_{2}(\mathrm{OH})_{2}(\mathrm{~g})$. In doing so, we need to recognize that these volatilities may be reduced because of interactions of $\mathrm{PuO}_{2} / \mathrm{AmO}_{2}$ with incinerator ash thus lowering the $\mathrm{PuO}_{2} / \mathrm{AmO}_{2}$ activities. Also, if a high halogen content is produced in the combustion gases, gaseous oxyhalides of $\mathrm{Pu}$ and $\mathrm{Am}$ may add to the overall $\mathrm{Pu}$ and $\mathrm{Am}$ volatilities. For purposes of illustration, we take the incinerator operating conditions as 1 atm total pressure with 0.1 atrn $\mathrm{O}_{2}(\mathrm{~g})$ and 0.1 atm $\mathrm{H}_{2} \mathrm{O}(\mathrm{g})$, and a gas flow rate of $40 \mathrm{kmols} / \mathrm{h}$. Incinerator temperatures are taken over the range of $550 \mathrm{C}$ to $1500 \mathrm{C}$. Operational time is taken as $6000 \mathrm{~h} / \mathrm{y} . \mathrm{PuO}_{2}$ containing $200 \mathrm{ppm} \mathrm{AmO} 2$ in solid solution is assumed to be present in sufficient quantity to maintain the solid $\mathrm{PuO}_{2} / \mathrm{AmO}_{2}$ phase in the ash. Results are given in Table 8. We see that the volatilities of $\mathrm{Pu}$ and $\mathrm{Am}$ are strongly dependent upon temperature, as for example, an incinerator that operates at $1000^{\circ} \mathrm{C}$, shows a $10^{5}$ increase in $\mathrm{Pu}$ and $\mathrm{Am}$ volatilities as compared with an incinerator that operates at $550^{\circ} \mathrm{C}$.

\section{Summary and Conclusions}

We find by transpiration experiments that $\mathrm{Pu}$ and $\mathrm{Am}$ show very low but measurable volatilities at $1230-1430 \mathrm{~K}$ from interactions of $\mathrm{O}_{2}(\mathrm{~g})$ and $\mathrm{H}_{2} \mathrm{O}(\mathrm{g})$ with $\mathrm{PuO}_{2}(\mathrm{~s})$ and $\mathrm{PuO}_{2} / 2 \% \mathrm{AmO}_{2}(\mathrm{~s})$. The volatile species are taken to be dominantly $\mathrm{PuO}_{2}(\mathrm{OH})_{2}(\mathrm{~g})$ and $\mathrm{AmO}_{2}(\mathrm{OH})_{2}(\mathrm{~g})$ with vapor pressures of $\sim 10^{-10}$ atm $\mathrm{PuO}_{2}(\mathrm{OH})_{2}(\mathrm{~g})$ and $\sim 10^{-12}$ atm $\mathrm{AmO}_{2}(\mathrm{OH})_{2}(\mathrm{~g})$ under the measurement conditions. We estimate the accuracy to be within plus a factor of three to minus a factor of $1 / 3$ in the $\mathrm{PuO}_{2}(\mathrm{OH})_{2}(\mathrm{~g})$ pressure measurements and within plus a factor of 15 to minus a factor of $1 / 15$ in the $\mathrm{AmO}_{2}(\mathrm{OH})_{2}(\mathrm{~g})$ pressure measurements. Using thermodynamic relations to extend the data to the conditions of the secondary combustion chamber of the Rocky Flats Plant Fluidized Bed Incinerator, we obtain volatilization rates of $7 \times 10^{-6} \mathrm{~g} \mathrm{Pu} / \mathrm{y}$ and $4 \times 10^{-9} \mathrm{~g}$ Am/y. 
Table 8. Illustration of the dependence of $\mathrm{PuO}_{2}(\mathrm{OH})_{2}(\mathrm{~g})$ and $A \mathrm{mO}_{2}(\mathrm{OH})_{2}(\mathrm{~g})$ volatilization on incineration temperature in mixed waste incinerators. $\mathrm{Pu}$ and $\mathrm{Am}$ are assumed to be present as $\mathrm{PuO}_{2}(\mathrm{~s})$ with $200 \mathrm{ppm} \mathrm{AmO} 2$ in solid solution. Incinerator operating conditions are taken as $1 \mathrm{~atm}$ total pressure with $0.1 \mathrm{~atm} \mathrm{O}_{2}(\mathrm{~g})$ and $0.1 \mathrm{~atm} \mathrm{H}_{2} \mathrm{O}(\mathrm{g})$, and a gas flow rate of $40 \mathrm{kmols} / \mathrm{h}$. Operational time is taken as $6000 \mathrm{~h} / \mathrm{y}$.

\begin{tabular}{ccccc}
$\begin{array}{c}\mathrm{t}, \\
{ }^{\circ} \mathrm{C}\end{array}$ & $\begin{array}{c}\mathrm{pPuO}_{2}(\mathrm{OH})_{2}, \\
\text { atm }\end{array}$ & $\begin{array}{c}\mathrm{pAmO}_{2}(\mathrm{OH})_{2}, \\
\mathrm{~atm}\end{array}$ & $\mathrm{~g} \mathrm{Pu} / \mathrm{y}$ & $\mathrm{g} \mathrm{Am} / \mathrm{y}$ \\
\hline 550 & $2.5 \times 10^{-16}$ & $1.5 \times 10^{-19}$ & $1.4 \times 10^{-5}$ & $8.4 \times 10^{-9}$ \\
600 & $1.7 \times 10^{-15}$ & $9.5 \times 10^{-19}$ & $9.8 \times 10^{-5}$ & $5.5 \times 10^{-8}$ \\
700 & $4.5 \times 10^{-14}$ & $2.3 \times 10^{-17}$ & $2.6 \times 10^{-3}$ & $1.3 \times 10^{-6}$ \\
800 & $6.5 \times 10^{-13}$ & $3.0 \times 10^{-16}$ & $3.7 \times 10^{-2}$ & $1.7 \times 10^{-5}$ \\
900 & $5.9 \times 10^{-12}$ & $2.5 \times 10^{-15}$ & $3.4 \times 10^{-1}$ & $1.5 \times 10^{-4}$ \\
1000 & $3.8 \times 10^{-11}$ & $1.5 \times 10^{-14}$ & 2.2 & $8.9 \times 10^{-4}$ \\
1100 & $1.9 \times 10^{-10}$ & $7.2 \times 10^{-14}$ & 11.0 & $4.1 \times 10^{-3}$ \\
1200 & $7.4 \times 10^{-10}$ & $2.7 \times 10^{-13}$ & 42.0 & $1.6 \times 10^{-2}$ \\
\hline
\end{tabular}

\section{Appendix}

\section{Additional Experimental Details:}

The arrangements of the wool filters and collectors for the various runs were as follows: In runs \#1 to 3, a $1.5 \mathrm{~cm}$ long $\mathrm{Al}_{2} \mathrm{O}_{3}$ wool plug was placed just upstream of the boat, a $1.5 \mathrm{~cm}$ long $\mathrm{Al}_{2} \mathrm{O}_{3}$ wool plug (the dust filter) was placed immediately downstream of the boat, another $1.5 \mathrm{~cm}$ long $\mathrm{Al}_{2} \mathrm{O}_{3}$ wool plug followed that, and then a $5 \mathrm{~cm}$ long $\mathrm{Al}_{2} \mathrm{O}_{3}$ wool plug. Run \#1 was an initial heating of the ${ }^{239} \mathrm{PuO}_{2}$ sample in an $\mathrm{Ar} / \mathrm{O}_{2}$ gas flow (without $\mathrm{H}_{2} \mathrm{O}$ ) to $1325 \mathrm{~K}$ for 2 hours. In runs \#2 and 3 , the ${ }^{239} \mathrm{PuO}_{2}$ was exposed to $\mathrm{Ar} / \mathrm{O}_{2} / \mathrm{H}_{2} \mathrm{O}$ mixtures at $1322 \mathrm{~K}$ for 2 hours. The $\mathrm{Al}_{2} \mathrm{O}_{3}$ plugs downstream of the boat were submitted for $\mathrm{Pu}$ analyses for these three runs. However, we were unable to dissolve off the $\mathrm{Pu}$ from the $\mathrm{Al}_{2} \mathrm{O}_{3}$ wool, using hot $\mathrm{HNO}_{3} / \mathrm{HF}$, or several other acids or acid mixtures that were tried. The dust filter plug on run \#2 showed a high alpha count, sufficient for analysis by gamma counting. It was therefore analyzed by gamma counting and showed a Pu content of 14.2 micrograms and an Am content of 0.0075 micrograms (see Table 3). This value is useful for setting an upper bound to the amount of $\mathrm{PuO}_{2}$ dust carryover to be expected for the very fine particulate $\mathrm{PuO}_{2}$ sample used here. Activities on the $\mathrm{Al}_{2} \mathrm{O}_{3}$ plugs downstream were much lower indicating that the filter had effectively filtered out most of the $\mathrm{PuO}_{2}$ dust, or had reacted with the $\mathrm{PuO}_{2}(\mathrm{OH})_{2}(\mathrm{~g})$ to form a solid compound of 
$\mathrm{Pu}$. The amount of Am present in the deposit is enriched by a factor of 2 relative to $\mathrm{Pu}$ as compared with the starting sample, thus suggesting that $\mathrm{AmO}_{2}(\mathrm{OH})_{2}(\mathrm{~g})$ has a proportionately higher volatility than $\mathrm{PuO}_{2}(\mathrm{OH})_{2}(\mathrm{~g})$, and that a portion of the activity on the dust filter originated from reactive condensation of the gaseous $\mathrm{Pu}$ and $\mathrm{Am}$ oxyhydroxides. No further analyses were attempted on runs \#1 to 3.

Because of the problems of using $\mathrm{Al}_{2} \mathrm{O}_{3}$ wool plugs for dust filters and collectors, we switched to silica glass wool dust filters and collectors in all subsequent runs except for runs \#44 and 73, in which we used silica glass collection tubes. The following wool plug arrangements were used for the remaining runs. For runs \#4 to 11 , we used a $1.5 \mathrm{~cm}$ long $\mathrm{Al}_{2} \mathrm{O}_{3}$ wool plug upstream of the boat, a $1.5 \mathrm{~cm}$ long $\mathrm{SiO}_{2}$ glass wool dust filter immediately downstream of the boat followed by a $0.5 \mathrm{~cm}$ gap and then a $5 \mathrm{~cm}$ long $\mathrm{SiO}_{2}$ glass wool collector plug. For runs \#19 to 21, we used a $1.5 \mathrm{~cm}$ long $\mathrm{SiO}_{2}$ glass wool plug upstream of the boat, and two $5 \mathrm{~cm}$ long $\mathrm{SiO}_{2}$ glass wool collector plugs placed immediately downstream of the boat. No dust filter was used in these runs. In runs \#23 to 37 , we used a $1.5 \mathrm{~cm}$ long $\mathrm{SiO}_{2}$ glass wool plug upstream of the boat, a $1.5 \mathrm{~cm}$ long $\mathrm{SiO}_{2}$ glass wool dust filter immediately downstream of the boat followed by a $0.5 \mathrm{~cm}$ gap and then two $5 \mathrm{~cm}$ long $\mathrm{SiO}_{2}$ glass wool collector plugs. In runs \#44 and 73 , we again used a $1.5 \mathrm{~cm}$ long $\mathrm{SiO}_{2}$ glass wool plug upstream of the boat, a $1.5 \mathrm{~cm}$ long $\mathrm{SiO}_{2}$ glass wool dust filter immediately downstream of the boat followed by a $0.5 \mathrm{~cm}$ gap, and then a $1.5 \mathrm{~cm}$ dia $\times 12 \mathrm{~cm}$ long $\mathrm{SiO}_{2}$ glass collector tube joined on the downstream side with a 12/30 standard taper joint to a tube exiting the furnace. $\mathrm{A} \mathrm{SiO}_{2}$ glass wool plug was wrapped around the sampling tube near the entrance end to provide a diffusion barrier inside the furnace tube, and $\mathrm{SiO}_{2}$ glass wool was loosely placed inside the sampling tube to provide additional surface area for condensation.

Cotton swabs were also used for diagnostic tests on a number of the runs to test for residual Pu or Am deposits on the furnace tube walls in the region of the silica glass wool collectors and further downstream. These cotton swab tests are described further down in this report.

We found that the Pu and Am could be dissolved from both the silica glass wool and from the cotton swabs by digesting in an acid mixture containing $8 \mathrm{M} \mathrm{HNO}, 0.1 \mathrm{M}$ $\mathrm{HF}$, and $\mathrm{O}_{1} \mathrm{M} \mathrm{H}_{2} \mathrm{SO}_{4}$. After digestion, each solution from the $\mathrm{PuO}_{2}$ tests was filtered, and an aliquot evaporated to dryness on a $2.5 \mathrm{~cm}$ dia planchet. In samples from the $\mathrm{PuO}_{2} / 2 \% \mathrm{AmO}_{2}$ tests, each filtered solution was passed through an ion exchange column to separate Pu and Am into fractions prior to evaporation on a planchet. Gross alpha activity on the planchets was measured using a dual chamber Ortec alpha spectrometer system composed of models 778,6719 and 576 counter, timer, and chamber components. The system was standardized for $\mathrm{Pu}$ and $\mathrm{Am}$ determinations with standard solutions of $\mathrm{Pu}$ of appropriate isotopic composition and a standard $241 \mathrm{Am}$ solution. The concentrations of Pu and Am were calculated taking into account the measured alpha counts, the volumes of the digested solutions and of the aliquots evaporated on the planchets, the specific activity of the Pu isotopic mix or separated $241 \mathrm{Am}$ fraction, and the counting system efficiency. For the silica glass collection tubes, which also contained some silica glass wool packing inside the tubes, we used 
a mixture of concentrated $\mathrm{HCl}$ and $\mathrm{HF}$ for the dissolution. This dissolved the $\mathrm{Pu}$ and Am and also dissolved the silica glass wool and etched the surface of the silica tube. The dissolved silica was removed as $\mathrm{SiF}_{4}(\mathrm{~g})$ by heating with excess $\mathrm{HF}$, then aliquot portions were taken of the solution, taken to dryness on planchets and counted for alpha activity using pulse height analysis to determine both $\mathrm{Pu}$ and $\mathrm{Am}$. On two of the $239 \mathrm{PuO}_{2}$ runs (runs \#6 and \#8), we carried out analyses on the collector plugs by gamma counting, and then analyzed them by the chemical dissolution and alpha counting method. For run \#6, we obtained $1.1 \mu \mathrm{g}$ Pu by gamma counting and $0.85 \mu \mathrm{g}$ Pu by alpha counting, and for run \#8, we obtained $1.2 \mu \mathrm{g}$ Pu by gamma counting and $1.4 \mu \mathrm{g} \mathrm{Pu}$ by alpha counting. The agreement appears to be within about $20 \%$ by the two methods. We have used the average of the two types of analytic results for runs \#6 and 8 in Table 3.

Beginning with run \#6, diagnostic surveys were carried out using surface alpha counting of silica glass plugs and cotton swabs to evaluate $\mathrm{PuO}_{2}$ dust transport, condensate on the furnace tube walls, and background contamination problems from the glovebox system. Surface measurements were made with a self-contained alpha survey count-rate-meter, LLNL model LEA75-1854. With this instrument, $0.1 \mu \mathrm{g}$ of $\mathrm{Pu}$ $(93.8 \% 239 \mathrm{Pu})$, dried from solution onto a planchet, measured 9,000-10,000 counts per min at approximately $2 \mathrm{~cm}$. We had found a spuriously high level of Pu deposit on the silica glass wool plug in run \#5 (see Table 3), that even exceeded the amount of Pu found on the dust filter of run \#2 (see Table 3). We believe that the high level of Pu occurred from pickup of background Pu during handling of the collector plug in the glovebox. After run \#6, to check the background $\mathrm{Pu}$ level inside the glovebox, we took paper swipe samples on the gloves, glovebox floor and walls, and apparatus surfaces and found alpha activity ranging from $4000-50,000$ counts $/ \mathrm{min}$. This can be compared with 30,000 counts/min of alpha found on the surface of the collector plug from run \#5. Before proceeding further, we wiped dowri all of the glovebox interior surfaces and the exposed equipment surfaces with lab wipes (paper towelettes) dampened with "Swish" (aqueous detergent cleaner). Then, to further minimize the pickup of background $\mathrm{Pu}$ contamination, we used the following procedures for handling of collector plugs and diagnostic swabs. The silica glass wool plugs were brought into the glovebox in a sealed plastic bag. The bag was opened and the plug inserted into the furnace tube using the bag as a holder to make the insertion. A metal rod with a disk on the end was cleaned with "Swish" on a lab wipe, and used to push the plug into position. After the run, a wire with a hook on the end was wiped off with "Swish" on a lab wipe, and used to pull the plug out of the furnace tube and drop it into a clean screwcap plastic container. After removai of the collector plug, a long-handled cotton swab with a plastic handle was removed from a sealed plastic bag, wet with water and used to wipe down the inside walls of the furnace tube on the downstream side up to just short of the dust filter. The cotion swab was then snipped away from the handle and dropped into a clean screwcap plastic container. A second cotton swab was used to dry off and further wipe the same region of furnace walls, and was similarly 
transferred to a separate screwcap plastic container. The collector plugs and swabs were transferred to a hood, removed from the containers and counted with the alpha survey meter that had been checked against the $0.1 \mu \mathrm{g} 239 \mathrm{pu}$ reference.

Results of the diagnostic surveys are summarized in Table A-1. Run \#6A was a test for $\mathrm{PuO}_{2}$ dust transport. With the upstream wool plug, $\mathrm{PuO}_{2}$ and boat, and dust filter in piace, two clean silica glass wool plugs each $2 \mathrm{~cm}$ long were inserted downstream of the dust filter, and Ar was run through the furnace tube at $500 \mathrm{~cm} 3 / \mathrm{min}$ for 1 hour. After the run, we found 250 counts/min alpha activity on a dry swab sample taken of the furnace tube wall downstream of the plugs. We found 6000 counts/min alpha activity on the first collector plug (nearest the boat) and only 500 counts/min on the second plug. A dry swab taken of the furnace tube wall downstream of the dust filter after removal of the plugs showed 2000 counts/min alpha. These results may be indicative of some dust pickup by the first plug, or the plug may have picked up some contamination from the furnace tube walls from prior runs. There was no evidence that any dust had gotten past the plugs, or it would have been picked up by the first swab. Run \#10 was another test for $\mathrm{PuO}_{2}$ dust transport. A new clean tube, a clean dust filter, and clean collection plug were used for the test, with the $\mathrm{PuO}_{2}$ sample and boat and the upstream filter in place. The tube had a constriction between the dust filter and the collector plug that narrowed the passage to $1 \mathrm{~cm}$ in diameter, which arrangement channels the flow and the dust particles through the center of the dust filter, thus minimizing any leakage between the dust filter and the wall. The run was made at $823 \mathrm{~K}$ for 2 hours under $500 \mathrm{~cm}^{3} / \mathrm{min}$ flow of $\mathrm{O}_{2}$, but without $\mathrm{H}_{2} \mathrm{O}$ present. No volatility of $\mathrm{Pu}$ is expected without $\mathrm{H}_{2} \mathrm{O}$. From $200-500$ counts/min of alpha activity were found for the collector plug and for the wet and dry swabs. We surmise that this is the level of Pu activity to expect because of background contamination from the glovebox environment during handling of the collector plugs and swabs. Because of the low level of activity, we conclude that $\mathrm{PuO}_{2}$ dust transport did not occur. Run \#13 was made to test for variation of $\mathrm{Pu}$ condensate with distance in the collector plugs. Eight plugs each $1.3 \mathrm{~cm}$ long, were placed next to each other, and a run was made at $1430 \mathrm{~K}$ for 1 hour with $500 \mathrm{~cm}^{3} / \mathrm{min} \mathrm{O}_{2}$ flow and 0.078 atm of $\mathrm{H}_{2} \mathrm{O}$ present. Alpha counts were found to all be low and randomly distributed at 100-200 counts/min, so that a distribution of Pu condensate could not be distinguished. This run was also indicative of no $\mathrm{PuO}_{2}$ dust transport. In runs \#19,20, and 21, dust filters were not used. There was no evidence for dust transport in these runs, nor any evidence for volatility above the background level of up to about 500 counts/min of alpha associated with handling of the samples in the glovebox. We believe the low levels of dust transport and volatility observed here are a result of the high degree of sintering that has occurred in the $\mathrm{PuO}_{2}$ sample (see more discussion later). In run \#23, in which we made the first run with the $\mathrm{PuO}_{2} / 2 \% \mathrm{AmO}_{2}$ sample, with run conditions of $1218 \mathrm{~K}$ for $250 \mathrm{~min}$ with $500 \mathrm{~cm}^{3} / \mathrm{min} \mathrm{O}_{2}$ flow and $0.084 \mathrm{~atm} \mathrm{H}_{2} \mathrm{O}$, we carried out chemical analyses for $\mathrm{Pu}$ and $\mathrm{Am}$ on the separate collector plugs and swabs and obtained: collector plug \#1, $0.044 \mu \mathrm{g} \mathrm{Pu}$ and $0.003 \mu \mathrm{g} \mathrm{Am}$; collector plug \#2, $0.008 \mu \mathrm{g}$ Pu and $0.004 \mu \mathrm{g} \mathrm{Am}$; wet swab, $0.062 \mu \mathrm{g} \mathrm{Pu}$ and $0.004 \mu \mathrm{g} \mathrm{Am}$; and dry swab, 0.064 $\mu \mathrm{g} \mathrm{Pu}$ and $0.004 \mu \mathrm{g} \mathrm{Am}$. It is apparent that a significant fraction of the Pu and Am condensate was picked up by the swabs. On subsequent runs therefore we combined 
Table A-1. Summary of alpha activity surveys of dust filters, collector plugs, and wet and dry swabs used to wipe off the Inner walls of the furnace tubes. The alpha activity Is measured with an alpha survey meter at $-2 \mathrm{~cm}$ from the surface of the sample.

\begin{tabular}{|c|c|c|c|c|c|c|}
\hline \multirow[b]{2}{*}{$\begin{array}{l}\text { nun } \\
\#\end{array}$} & \multirow[b]{2}{*}{$\begin{array}{l}\text { furnace } \\
\text { tube a }\end{array}$} & \multicolumn{5}{|c|}{ alpha activity counts per min } \\
\hline & & $\begin{array}{l}\text { dust } \\
\text { filter }\end{array}$ & $\begin{array}{l}\text { collector } \\
\text { plug \# } 1\end{array}$ & $\begin{array}{l}\text { collector } \\
\text { plug \# } 2\end{array}$ & $\begin{array}{l}\text { wet } \\
\text { swab }\end{array}$ & $\begin{array}{l}\text { dry } \\
\text { swab }\end{array}$ \\
\hline$\overline{4}$ & $\bar{B}$ & & & & & \\
\hline 5 & B & 30,000 & & & & \\
\hline 6 & B & & 4000 & & 2000 & 2000 \\
\hline $6 A^{b}$ & $B$ & & 6000 & 500 & & 2000 \\
\hline 8 & B & & 8000 & & 800 & 1000 \\
\hline 9 & B & & 4000 & & 600 & \\
\hline $10^{c}$ & D & & 300 & & 500 & 200 \\
\hline 11 & D & 10,000 & 1000 & & 3000 & 2000 \\
\hline $13^{d}$ & D & & $100-200^{d}$ & & 400 & 300 \\
\hline $19^{e}$ & D & & 100 & 200 & 300 & 300 \\
\hline $20^{e}$ & D & & 400 & 100 & 300 & 1000 \\
\hline $21^{e}$ & D & & 200 & 200 & 400 & 500 \\
\hline 23 & D & & 2000 & 1000 & 1000 & 4000 \\
\hline 24 & D & & 2000 & 600 & 600 & 400 \\
\hline 25 & D & & 6000 & 400 & 300 & 500 \\
\hline 28 & D & & 1000 & 2000 & 300 & \\
\hline 32 & $E$ & & 4000 & 2000 & 400 & 2000 \\
\hline 33 & $E$ & 60,000 & 2000 & 500 & 1000 & 400 \\
\hline 34 & $E$ & & 2000 & 400 & 2000 & 10,000 \\
\hline $35^{f}$ & $E$ & & 4000 & 4000 & 400 & 300 \\
\hline 36 & $E$ & & 500 & 5000 & 600 & 3000 \\
\hline 37 & 1 & 30,000 & 1000 & 2000 & 200 & 300 \\
\hline 44 & 8 & & 20009 & & & \\
\hline 73 & 15 & & & & & \\
\hline
\end{tabular}

a Furnace tubes $D$ and $E$ had a constriction in the tube between the dust filter and the first collector plug, narrowing the passage to $1 \mathrm{~cm}$ in diameter. Furnace tubes $\mathrm{B}, 1$, and 8 were smooth bore. New tubes were used for runs $4,10,37,44$, and 73.

b This was a run made to check for dust transport. With the front plug, $\mathrm{PuO}_{2}$ sample and boat. and dust filter in place, two clean silica glass wool plugs each $2 \mathrm{~cm}$ long were placed in the tube past the dusi filter and Ar was run through at $500 \mathrm{~cm}^{3}$ for 1 hour with the furnace cold.

C This was a run made to check for dust transport. It was run at $823 \mathrm{~K}$ for 2 hours under $500 \mathrm{~cm}^{3} / \mathrm{min}$ flow of $\mathrm{O}_{2}$.

d This run was made to check for variation of Pu condensate with distance along the length of the collector plug. Eight plugs, each $1.3 \mathrm{~cm}$ long, were placed next to each other, and a run was made at 1 $430 \mathrm{~K}$ for 1 hour with $500 \mathrm{~cm}^{3} / \mathrm{min} \mathrm{O}_{2}$ flow and 0.078 atm $\mathrm{H}_{2} \mathrm{O}$ present. Surface alpha counts on the plugs were all found to be low at $100-200$ counts/min.

e Dust filters were not used in these runs.

f This was a run without furnace operation in which the clean collector plugs were inserted into position and then removed and checked for alpha counts.

9 Counts are for plug supporting inlet to the sampling tube. 
the two collector plugs and two swabs in one batch for analysis, except for run \#28, where we only used the two collector plugs, and for runs \#44 and 73, where we used silica glass collector tubes. In run \#34, which was made at $1334 \mathrm{~K}$ for 5 hours with 50 $\mathrm{cm}^{3} / \mathrm{min} \mathrm{O}_{2}$ flow and 0.458 atm $\mathrm{H}_{2} \mathrm{O}$, we found a fairly high activity of 10,000 counts/min alpha on the dry swab. To test the effect of transfer of any residual deposit to the next run, we carried out a dry run (run \#35) in which clean collector plugs were inserted into position and then removed without operating the furnace. This was followed by a wet and dry swab. The collector plugs showed fairly high activity at 4000 counts/min of alpha each, while the counts on the swabs had dropped to background. This indicates that the collector plugs (which fit snugly in the furnace tube) were effective in removing the residual $\mathrm{Pu}$ and Am from the previous run off the walls. We expect that some transfer of Pu and Am condensate occurred in all the runs where we reused the tubes.

We roted the effect of sample sintering resulting in low volatility in runs \#19,20, and 21. Prior to run \#19, the $\mathrm{PuO}_{2}$ sample had accumulated run times of 17 hours at $1330 \mathrm{~K}$ plus $51 / 2$ hours at $1430 \mathrm{~K}$. The presence of water vapor probably accelerated the sint?ring. Visual observation showed the sample to have the appearance of grains of sand. X-ray diffraction showed a spoity pattern indicating large crystals. The low surface area from the sintering would make it more difficult to attain equilibrium, especially at the high gas flow rates used in these runs. The amounts of Pu analyzed in the collection plugs for these three runs are very low and subject to background contamination during handling, so that the actual volatilized amounts are even less than shown. In the runs on the $\mathrm{PuO}_{2} / 2 \% \mathrm{AmO}_{2}$ samples, we followed the effects of sintering on equilibration mare carefully. After an initial heat treatment of the sample at $1330 \mathrm{~K}$ for 4 hours, we made run $\# 23$ at $1218 \mathrm{~K}$ and run $\# 24$ at $1331 \mathrm{~K}$ and obtained the expected $\mathrm{Pu}$ volatilities for these runs (see Fig. 2 where $\mathrm{log} \mathrm{K}_{\mathrm{eq}}$ for the volatilization reaction is shown as a function of $1 / T$ ). In run \#25 made at $1433 \mathrm{~K}$ for 65 min, we found an apparent drop off in $\mathrm{Pu}$ volatility, although probably within experimental error. This would suggest sintering was becoming important at $1433 \mathrm{~K}$. By run \#32, the $\mathrm{PuO}_{2} / 2 \% \mathrm{AmO}_{2}$ sample had accumulated run times of 6 hours at 1330 $\mathrm{K}$ plus 11 hours at $1430 \mathrm{~K}$. Run \#32 was made at $1434 \mathrm{~K}$ for 6 hours with an $\mathrm{O}_{2}$ flow rate of $100 \mathrm{~cm} 3 / \mathrm{min}$, which was a much lower flow rate than in previous runs. The volatility obtained for $\mathrm{Pu}$ was found to be considerably reduced in run \#32, which we attribute to sintering. The lower flow rate of gas used should have improved the approach to equilibrium because of the longer residence time of the gas, but the lowered surface area of the sample from sintering apparently was a more significant factor. For run \#33, we ground up the $\mathrm{PuO}_{2} / 2 \% \mathrm{AmO}_{2}$ sample in a mortar and pestle, and carried out the run at $1434 \mathrm{~K}$ for 3 hours with an $\mathrm{O}_{2}$ flow rate of $50 \mathrm{~cm} 3 / \mathrm{min}$. The volatility of $\mathrm{Pu}$ was considerably increased in this run but still appeared somewhat low (see Fig. 2). Some sintering may still have occurred since the sample was at $1434 \mathrm{~K}$ for 3 hours. The sample was rerun (run \#34), without grinding, at $1334 \mathrm{~K}$ for 6 hours with an $\mathrm{O}_{2}$ flow rate of $50 \mathrm{~cm} 3 / \mathrm{min}$, and showed a lowered $\mathrm{Pu}$ volatility similar to run \#33. Apparently no further sintering occurred at this lower temperature. The sample was reground and run again in run \#36 at $1229 \mathrm{~K}$ for 10 hours under $50 \mathrm{~cm} 3 / \mathrm{min} \mathrm{O} 2$ flow. The Pu volatility was found to be up to the expected level (see Fig. 2). Again no significant sintering seems to occur at this low temperature. The sample was then 
used without grinding for the low temperature run, run \#37, at $825 \mathrm{~K}$. It was next used for run \#44 at $1431 \mathrm{~K}$ for 10 hours with $50 \mathrm{~cm} 3 / \mathrm{min} \mathrm{O}_{2}$ flow. The sample was first ground prior to the run. The run was made for 7 hours and stopped. The sample was ground again, and the run continued for an additional 3 hours. The Pu volatility was found to be somewhat below the expected curve as was the case with runs \#25, 33, and 34 , suggesting again sintering effects at $1430 \mathrm{~K}$. 


\section{References}

1. 7. H. Krikorian, "Predictive Calculations of Volatilities of Metals Metals and kides in Steam-Containing Environn.ants," High Temp.-High Press., 14, 387397 (1982).

2. O. H. Krikorian, "Analysis of Plutonium and Uranium Volatilities from Mixed Wastes in the Molten Salt Processor," in Proceedings of the 1991 Incineration Conference at Knoxville. Tennessee. May 13-17, 1991, Univ. of California, EH\&S, Irvine, CA 92109, 1991, pp 311-320.

3. R. S. Upadhye, M. G. Adamson, J. F. Cooper, and A. K. Lee, "An Investigation of the Need for the Hold, Test and Release (HT\&R) Option for the Rocky Flats Fluidized Bed Unit (FBU)," Lawrence Livermore National Laboratory Unpublished Report, L-14805, June 1992.

4. O. H. Krikorian, R. H. Condit, B. B. Ebbinghaus, A. F. Fontes, D. L. Fleming, C. L. Hoenig, R. A. Otto, J. W. Magana, and W. F. Morris, "Evaluation of Actinide Volatilities in Mixed Waste Processors: Interim Report," Lawrence Livermore National Laboratory Report, UCRL-ID-111352, Aug. 24, 1992.

5. O. H. Krikorian, R. H. Condit, A. F. Fontes, W. F. Morris, and J. W. Magana, "Study of Plutonium Volatility under Microwave Melting Conditions used for Glass Encapsulation of Plutonium Sludge Wastes: An Interim Report," Lawrence Livermore National Laboratory Report, UCRL-ID-111665, Sept. 25, 1992.

6. L. F. Grantham, D. E. McKenzie, W. L. Richards, and R. D. Oldenkamp, "Molten Salt Combustion of Radioactive Wastes," Proc. ERDA Air Clean. Conf. 1976, 14 (1), 17-35 (1977).

7. D. E. McKenzie, L. F. Grantham, R. B. Paulson, W. L. Richards, and R. B. Rennick, "Disposal of Transuranic Solid Waste using Atomics International Molten Salt Combustion Process," Rockwell International Report, Al-ERDA-13151, May 5, 1975.

8. L. F. Grantham, D. E. McKenzie, R. D. Oldenkamp, and W. L. Richards, "Disposal of Transuranic Solid Waste using Atomics International Molten Salt Combustion Process, II," Rockwell International Report, Al-ERDA-13169, Mar. 15, 1976.

9. M. W. Chase, Jr., C. A. Davies, J. R. Downey, Jr., D. J. Frurip, R. A. McDonald, and A. N. Syverud, JANAF Thermochemical Tables, Third Edition, Parts I and II (J. Phys. Chem. Ref. Data, 14, 1985, Supplement No. 1), American Chemical Society and American Institute of Physics, New York, 1986.

10. O. Glemser and R. V. Haeseler, "About Gas-Forming Hydroxide of Molybdenum and Tungsten," Z. Anorg. Allg. Chem., 316, 168-181 (1962). 
11. F. D. Richardson and C. B. Alcock, "Chemical Equilibria," in Physicechemical Measurements at High Temperatures, edited by J. O'M. Bockris, J. L. White, and J. D. Mackenzie, Butterworths Sci. Publ., London, 1959, pp 135-170.

12. R. Diehl, G. Brandt, and E. Salje, Acta Crystallogr., B, 34, 1105-1111 (1978).

13. B. O. Loopstra and P. Boldrini, Acta Crystallogr., 21, 158-162(1966).

14. W. L. Kehl, R. G. Hay, and D. Wahl, J. Appl. Phys., 23, 212-215 (1952).

15. E. H. P. Cordfunke, R. J. M. Konings, P. E. Potter, G. Prins, and M. H. Rand, Ihermochemical Data for Reactor Materials and Fission Products, Eds. E. H. P. Cordfunke and R. J. M. Konings, North Holland, Amsterdam, 1990.

16. S. R. Dharwadkar, S. N. Tripathi, M. D. Karkhanavala, and M. S. Chandrasekharaiah, "Thermodynamic Properties of Gaseous Uranium Hydroxide," in Thermodynamics of Nuclear Materials 1974. Vol. II. Procedings of a Symposium, Vienna, 21-25 October 1974, International Atomic Energy Agency, Vienna, 1975, pp 455-465.

17 B. B. Ebbinghaus, "Thermodynamics of Gas Phase Chromium Species I. The Chromium Oxides, The Chromium Oxyhydroxides, and Volatility Calculations in Waste Incineration Processes," Lawrence Livermore National Laboratory Report, UCRL-JC-110326 PREPRINT, April 7, 1992, submitted for publication in Combustion and Flame.

18. L. J. Meile, F. G. Meyer, A. J. Johnson, and D. L. Ziegler, "Rocky Flats Plant Fluidized Bed Incinerator," Rockwell International Rocky Flats Plant Report, RFP3249, DOE/TIC-4500, March 8, 1982.

19. B. W. Logsden, EG\&G Rocky Flats Plant, private communication, January 15, 1993. 

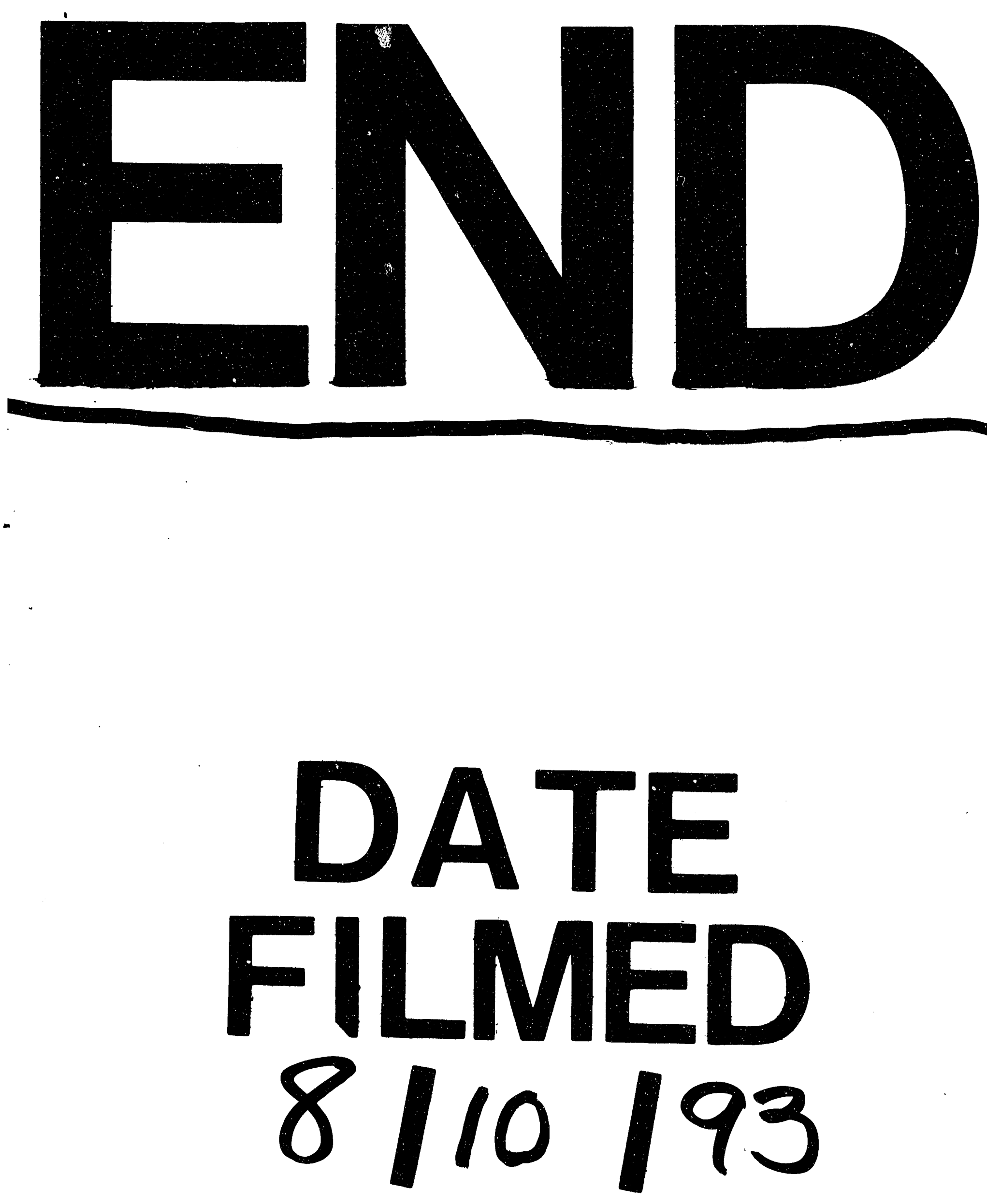
1 